NBER WORKING PAPER SERIES

\title{
CHINA'S EXPERIENCE UNDER THE MULTIFIBER ARRANGEMENT (MFA) AND THE AGREEMENT ON TEXTILES AND CLOTHING (ATC)
}

\author{
Irene Brambilla \\ Amit Khandelwal \\ Peter Schott \\ Working Paper 13346 \\ http://www.nber.org/papers/w13346
}

\author{
NATIONAL BUREAU OF ECONOMIC RESEARCH \\ 1050 Massachusetts Avenue \\ Cambridge, MA 02138 \\ August 2007
}

Special thanks to Ronald Foote of the U.S. Census Bureau and Ross Arnold and Keith Daly of the U.S. Office of Textiles and Apparel (OTEXA). We thank Judy Dean, Rob Feenstra, Joseph Francois and James Harrigan for helpful comments and suggestions. Excellent research assistance was provided by Matthew Flagge and Rocky Huarng. This material is based upon work supported by the National Science Foundation under Grant No. 0241474. Any opinions, findings, and conclusions or recommendations expressed in this material are those of the authors and do not necessarily reflect the views of the National Science Foundation or the National Bureau of Economic Research.

(C) 2007 by Irene Brambilla, Amit Khandelwal, and Peter Schott. All rights reserved. Short sections of text, not to exceed two paragraphs, may be quoted without explicit permission provided that full credit, including $\odot$ notice, is given to the source. 
China's Experience Under the Multifiber Arrangement (MFA) and the Agreement on Textiles and Clothing (ATC)

Irene Brambilla, Amit Khandelwal, and Peter Schott

NBER Working Paper No. 13346

August 2007, Revised February 2009

JEL No. F1,F13,F15

\section{ABSTRACT}

This paper analyzes China's experience under U.S. apparel and textile quotas. It makes use of a unique new database that tracks U.S. trading partners' performance under the quota regimes established by the global Multifiber Arrangement (1974 to 1995) and subsequent Agreement on Textiles and Clothing (1995 to 2005). We find that China was relatively more constrained under these regimes than other countries and that, as quotas were lifted, China's exports grew disproportionately. When the ATC finally ended in 2005, China's exports surged while those from nearly all other regions fell.

Irene Brambilla

Yale University

Department of Economics

37 Hilllhouse

P. O. Box 208264

New Haven, CT 06520-8264

and NBER

irene.brambilla@yale.edu

Amit Khandelwal

Columbia Business School

Uris Hall 606, 3022 Broadway

New York, NY 10027

amit.khandelwal@mail.gsb.columbia.edu
Peter Schott

Yale School of Management

135 Prospect Street

New Haven, CT 06520-8200

and NBER

peter.schott@yale.edu 


\section{Introduction}

On January 1, 2005, restrictions on the fourth and final set of textile and clothing products regulated by the Agreement on Textile and Clothing (ATC), the successor of the Multifiber Arrangement (MFA), were removed. The gradual expiration of these quotas starting in 1995 ended decades of bilateral non-tariff-barrier protection in this industry and set the stage for a substantial reallocation of production and exports across countries. Though many analysts expected China's share of the United States' textile and clothing (T\&C) imports to rise when the ATC expired in 2005, predictions varied widely. ${ }^{1}$ In fact, China's overall T\&C export quantities to the U.S. increased 39 percent in 2005, with exports of goods whose quotas were relaxed in the beginning of that year jumping 270 percent.

This paper uses a new dataset of U.S. import quotas to examine China's relative performance in the U.S. market under the ATC. Our analysis reveals that China's T\&C exports to the U.S. were relatively restrained along three dimensions. First, China's quotas were more likely to be binding than the quotas imposed on other countries. Second, China's quotas grew at a slower rate than the quotas of most other countries. Finally, the U.S. appears to have placed relatively greater restrictions on China's ability to shift quota allocations across different categories of goods or across years.

China's rapid increase in U.S. market share as quotas were relaxed came at the expense of both domestic manufacturers and the United States' other trading partners. We show that T\&C exports from virtually all countries decreased in 2005, and that for some regions, e.g., Sub-Saharan Africa, these declines represented an abrupt reversal of several years of previously robust T\&C export growth. These reversals suggest that, over time, the MFA and ATC had evolved from a regime intended to protect domestic U.S. manufacturers into one which also guaranteed smaller developing countries access to the U.S. market. Among developing countries, only those from South Asia managed to defend market share in the face of substantial Chinese growth, but even South Asia's response was not uniform across products.

T\&C quotas under the ATC were relaxed in four phases. Though China's response to the final phase of reductions was dramatic, it was predictable given China's reaction to earlier quota relaxations, particularly when one focuses on goods for which China's quotas were binding. China, being outside the WTO, was ineligible for the first two phases of quota reductions in 1995 and 1998. After joining the WTO in December 2001, its quotas on these goods, as well as its quotas on Phase III goods, were lifted simultaneously in January 2002.

The four panels of Figure 1 trace out China's U.S. exports of T\&C goods according to

\footnotetext{
${ }^{1}$ For example, the computational general equilibrium (CGE) study by Rivera et al (2003) predicted that China's textile and apparel exports would increase between 8 and 104 percent, respectively, following the elimination of quotas in developed countries. Nordas (2004) predicted that China's post-MFA/ATC textile and clothing market share in the U.S. would increase by 7 and 34 percentage points, respectively. Diao and Somwaru (2001) estimated a more moderate growth of 6 percent in Chinese T\&C exports to the world.
} 
the phase in which quotas were relaxed. Solid lines track the evolution of total exports, while dashed lines report China's exports in goods whose quotas were binding the year before removal. The vertial line in each panel notes the year in which China's quotas in each set of goods were relaxed. As indicated in the figure, China's exports of Phase I and II goods increased relatively modestly after quota removal (42 and 32 percent, respectively) compared with Phase III and Phase IV goods (305 and 271 percent, respectively). China's response in previously bound goods, by contrast, was substantially larger across the three Phases - II, III and IV - in which goods faced binding quotas, increasing 825, 322 and 330 percent, respectively. As we document below, China's Phase IV growth in 2005 appears to have had an especially large and negative impact on nearly all regions' exports that year.

Examination of export price changes under the ATC suggests a reallocation of exports within as well as across countries as quotas were relaxed. We find quota removal to be accompanied by large declines in export unit values across all U.S. trading partners. In the final phase, China's unit values in unbound versus bound products fell 31 and 41 percent, respectively. These declines, as well, were anticipated by previous phases of liberalization. Consistent with models of quality upgrading in response to quantitative restrictions, we also document evidence of relative quality downgrading within China's Phase IV products as their quotas were lifted.

The remainder of this paper is organized as follows. In Section 2 we briefly summarize the MFA and ATC regimes. Section 3 provides a detailed description of the contents of the U.S. MFA/ATC database constructed for this paper. Sections 4 and 5 examines countries quantity and unit value responses to quota relaxation. Section 7 concludes.

\section{The MFA and the ATC}

The Multifiber Arrangement grew out of a series of voluntary export restraints imposed, initially, by the United States on Japanese textile exports in 1955. By the end up the 1950s, the United Kingdom also began to limit imports from Hong Kong, India and Pakistan (Spinanger, 1999). Quotas on cotton textiles and apparel products were first institutionalized with the Short Term Arrangement in 1961, which was extended to two subsequent Long Term Arrangements throughout the 1960s and early 1970s. As the Asian economies' textile and apparel production continued to grow, developed countries sought a more systematic mechanism to deal with "market disruptions" in other fiber markets. This search lead to the signing of the Multifiber Arrangement, in 1974, which, although "temporary" at first, ultimately lead to an additional 30 years of protection. As a result of the MFA, T\&C products were kept out of multilateral trade negotiations under the General Agreement on Tariffs and Trade (GATT) and its successor, the World Trade Organization 
(WTO). ${ }^{2}$

A major development of the Uruguay Round was the signing of the Agreement on Textile and Clothing (ATC) in 1994. The ATC ended the MFA and began the process of integrating textile and clothing products into GATT/WTO rules by removing their quotas. Integration occurred over the four phases outlined in Table 1. During each phase, importing countries were to integrate a portion of all T\&C products covered by the ATC. The particular products integrated in each phase importing-country specific but subject to two rules. First, the products retired in each phase had to include goods from all four major textile and clothing segments, i.e., Yarn, Fabrics, Made-Up textile products (e.g., table linen, carpets and curtains), and Clothing. Second, the chosen products had to represent a set portion of each country's 1990 T\&C imports, by volume. In Phase I, which began on January 1, 1995, countries had to integrate products representing 16 percent of their 1990 import volumes. An additional 17 and 18 percent of 1990 export volumes were integrated at the beginning of Phases II and III on January 1, 1998 and January 1, 2002, respectively. Finally, on January 1, 2005, Phase IV of the ATC culminated in the integration of the remaining 49 percent of export volumes and all quotas were abolished.

Perhaps unsurprisingly given countries' ability to choose which quotas to retire in each phase, quotas removed during the first two phases of the ATC were in general not very painful for producers in developed countries. In the United States, ATC products accounted for 17.1 billion square meter equivalents (SME) worth of imports in 1990. ${ }^{3}$ However, U.S. imports of products actually subject to quotas in that year totalled just 12.2 billion SMEs (USITC, 2004). As a result, the U.S. found it relatively easy to defer removal of quotas on "sensitive" products until the third phase. Products such as tents and life jackets, for example, were included in the ATC but had not been subject to U.S. import quotas. The United States integrated these products in the first phase. As indicated in the final column of Table 1, the United States retired a total of 4,875 ten-digit Harmonized System (HS) product codes across the four phases, of which 62 percent were retired in 2005. In this paper, these HS codes are our definition of the set of T\&C products imported by the United States and governed by the ATC. ${ }^{4}$

In addition to gradually removing quotas, the ATC improved developing countries' access to developed-country markets by accelerating quota growth over the four phases of quota removal. These changes were governed by what is referred to as the ATC's "growthon-growth" provision and are summarized in the third column of Table 1. At the beginning of Phase I, existing quota growth rates were accelerated 16 percent per year, while they

\footnotetext{
${ }^{2}$ For a more extensive discussions of the road to the ATC, see Spinanger (1999) and Francois and Worz (2006).

${ }^{3}$ Product quotas under the MFA and ATC were set in terms of square meter equivalents (SME), with each product having an explicit "conversion factor" to determine the SME of their native units (e.g., pairs of socks). Examples of SME are provided in Table 4.

${ }^{4}$ We are grateful to Keith Daly at OTEXA for providing us with this list.
} 
were accelerated by 25 and 27 percent in Phases II and III, respectively. A group with a base quota growth rate of 6 percent in 1994, for example, would grow at 6.96 percent $\left(0.06^{*} 1.16\right)$ per year during Phase I, 8.7 percent $\left(0.0696^{*} 1.25\right)$ per year over Phase II, and $11.05\left(0.087^{*} 1.27\right)$ percent per year during Phase III. ${ }^{5}$

China's exclusion from the WTO prior to 2001 rendered it ineligible for ATC integration benefits during its first two phases. After China was admitted formally into the WTO on December 11, 2001, the United States removed its quotas on China's Phase I and II imports simultaneously with the quotas on its Phase III goods on the scheduled Phase III removal date, i.e., January 1, 2002. After WTO accession, China also received growth rate increases consistent with the ATC. ${ }^{6}$

As part of its entry into the WTO, China agreed to special safeguard provisions, subject to "consultations," that would limit its exports to countries experiencing market disruptions after the ATC was phased out. Under the guidelines governing China's accession into the WTO, WTO members could enter negotiations for new safeguards on Chinese products provided those countries could show evidence of the existence or threat of a market disruption and a role for Chinese goods in that disruption (WTO 2001). The safeguard provision is applicable until December $31,2008 .^{7}$

When quotas on the final set of products expired on January 1, 2005, domestic textile and apparel industry groups successfully lobbied for new safeguards against China on 22 MFA groups of products, and they remain effective until the end of 2008. However, the U.S. and China reached a memorandum of understanding that the U.S. would "exercise restraint" on additional safeguards. Table 2 lists the quota levels that are operative until 2008.

\section{The U.S. MFA/ATC Database}

This section describes our construction of the U.S. MFA/ATC database and summarizes its contents. The database is assembled from U.S. trading partners' Expired Performance Reports, which were used by the U.S. Office of Textile and Apparel (OTEXA) to monitor trading partners' compliance with the MFA and ATC quotas. Generously provided by Ron Foote of the U.S. Census Bureau, they document imports, base quotas and quota adjustments (defined below) by groups of products (referred to as "MFA groups") and year for all countries with which the United States negotiated bilateral quota arrangements. The

\footnotetext{
${ }^{5}$ Quota growth acceleration was advanced one phase for countries with less than 1.2 percent of the importing country's total quotas in 1991.

${ }^{6}$ China's growth rates were increased by 27 percent plus an additional pro-rated increase to account for its 3 weeks of WTO membership in 2001 (USITC, 2004).

${ }^{7}$ For additional details regarding the post-ATC Chinese safeguards, see Whalley and Dayaratna-Banda (2007).
} 
database covers 1984 to $2004 .^{8}$

Between 1984 and 2004 the U.S. signed bilateral MFA/ATC agreements with the 71 countries listed in Table 3. Seven of these countries - Barbados, Canada, Lebanon, Pacific Islands, Portugal, Spain and Trinidad and Tobago - were not subject to what is known as "specific limits," the most restrictive quota classification and the focus or our analysis (see discussion below). The details of an agreement were negotiated over an "agreement term" which typically lasted several "agreement periods." For most countries, an agreement period corresponded to a full calendar year. ${ }^{9}$ The United States negotiated quotas on 149 three-digit MFA specific-limit groups; on average, each group contains 17 HS products. The MFA groups span four T\&C "segments:" Yarn, Fabric, Made-Ups and Clothing. Examples of MFA groups in each segment are provided in Table 4.

Quotas were negotiated on individual MFA groups as well as on both aggregations and subsets of groups, which are known as "merged" and "part" groups, respectively. As a result, country-year-group observations in the database actually encompass a mixture of groups, merged groups and part groups. For simplicity, we refer to all of these observations as being at the "group" level for the remainder of the paper.

The negotiated quota for any particular group is stated in terms of square meter equivalents (SME) of fabric. To pool potentially diverse groups with different native units - e.g., pairs of gloves and dozens of shirts - the ATC established "conversion factors" to concord native units into square meter equivalents. These conversion factors are used to aggregate base quotas and import levels and to provide a means of shifting quotas across groups with different units (e.g., shirts to socks).

The Expired Performance Reports refer to nine possible classifications of negotiated quantities. In this paper, we focus exclusively on "specific limit" quotas, which, according to OTEXA, were the most restrictive quotas used under the MFA/ATC. The other classifications are designated consultation levels, minimum consultation levels, other groups, restraint limits, guaranteed access levels, designated consultation provisions, agreed limits and tariff preference levels. Several of these designations are not actually quotas, but rather served as watch lists. Their application is noted in the MFA/ATC Database. ${ }^{10}$

Specific quotas grew at fixed, known rates over an agreement term. Overall, they grew

\footnotetext{
${ }^{8}$ Data for 1986 are missing. Refinement of the raw data is discussed in a technical Appendix available from the authors on request.

${ }^{9}$ For some countries, including Brazil, Indonesia and Sri Lanka, the agreement period in early years covered overlapping calendar years. All periods were standardized to match the calendar year under the ATC.

${ }^{10}$ For some countries, there was another layer of quotas known as "aggregate group limits." A specific limit was a group-specific quota while the group limit imposed an aggregate quota over several MFA groups. A group could therefore be bound by a specific limit (individual, merged or part), subject to an aggregate specific limit, or both. One potential explanation for aggregate limits is that it limited the use of flexibilities across MFA groups (see below). We ignore these aggregate limits in this paper but they are available in the MFA/ATC Database.
} 
an average of 6 percent per year, but growth varied across countries and groups. China, for example, faced annual specific quota growth rates of 1 to 2 percent, and wool products experienced slower growth than cotton goods. ${ }^{11}$

The U.S. MFA/ATC Database records the "base" quota, the "adjusted base" quota and the total exports for each specific limit by country and year. The base quota is the originally negotiated quota level determined at the start of an agreement term. Adjusted base quotas reflect the use of what are known as "flexibilities," which allowed countries to exceed their base quota in a given period by borrowing unused base quota, up to a specified percentage of the receiving group, across groups within a year and across years within a group. Countries could apply multiple flexibilities on a group and the adjustments had to be met by corresponding offsets in the lending groups.

There were three major flexibilities:

1. Carryforward and carryforward-used: A carryforward allowed countries to borrow base quota from the subsequent period within a group. A carryforward-used offset a carryforward. For example, in 1997 Macau carried forward 20,419 SME in group 338 ("Men/boys knit shirts"). The flexibility was then offset in 1998, under a carryforward-used, by -20,419 SME. Borrowing was subject to a country-product specific limit.

2. Carryover and shortfall-used: A carryover utilized unused quota from the previous period within a group, subject to a country-product specific maximum. A shortfallused offset a carryover.

3. Shift-add, shift-subtract, swing: Shift-add, shift-subtract, and swings allowed acrossgroup base movements within a year, subject to limits.

After accounting for all flexibilities, the adjusted base quota for a given year reflects the country-group deviation in that year from the original base quota. For example, China's 2002 base quota for group 219 ("duck fabric") was 2.6 million SME. China made two adjustments on this group that year. First, it borrowed 2 percent from the previous year's unused quota (carryover). Second, it added 5 percent of its original base quota from another group (swing). These adjustments resulted in an adjusted base quota of 2.8 million SME for group 219 in 2002. If a country made no adjustment on a group, the adjusted base quota simply remained at the base quota.

Table 5 compares countries' aggregate adjusted base quotas and exports across all groups from 1984 to 2004. Results are reported for the thirty countries with the largest aggregate

\footnotetext{
${ }^{11}$ We include only specific-limit groups in our examination of fill rates below. In our regression analysis, non-specific limit groups are treated as unbound; the regressions include all T\&C HS codes from all $\mathrm{T} \& \mathrm{C}$ exporters.
} 
adjusted base quotas. As indicated in the first two columns of the table, China, Taiwan and Hong Kong exhibit the highest levels of both adjusted base quota and exports between 1984 and 2004. The final column of Table 5 reports countries' aggregate "fill rates," which equal exports as a percentage of adjusted base quota. Although adjusted base quotas can exceed base quotas, fill rates cannot exceed 100 because they are defined as exports over adjusted base. As indicated in the table, Bangladesh, China, Indonesia, Pakistan, India and Sri Lanka all exhibit aggregate fill rates in excess of 80 percent over the sample period. Countries with relatively low fill rates include Jamaica, Guatemala, Colombia and Honduras.

Fill rates provide a useful indication of quota restrictiveness. We follow the USITC (and Evans and Harrigan 2005) in defining a binding quota as one in which the fill rate exceeds 90 percent. Here, too, results are reported for the thirty countries with the largest base quota. As indicated in Table 6, Bangladesh, India and China exhibited the largest share of binding quotas over the sample period, in each case above 60 percent. We note that using a more liberal or conservative definition for binding quotas, that is, fill rates of 80 and 95 percent, respectively, does not result in any substantial re-ranking of counties in terms of which are most constrained over the sample period.

Interestingly, we find that less than 30 percent of the quotas were binding for other major developing East Asian economies such as South Korea, Taiwan and Malaysia. Thus, even though these countries were subject to a relatively large fraction of specific limits (see Table 7), these limits appear to have been relatively weak. This outcome may be driven in part by these countries' relatively fast movement into more sophisticated manufactures over the sample period. Indeed, we show in the next section that the share of East Asian observations with binding quotas diminishes over time.

Heterogeneity in fill rates is also apparent across MFA groups. Table 8 reports aggregate fill rates for the ten largest MFA groups. Trousers and knit shirts are the most constrained groups, with exporters filling more than 80 percent of the allocated quota. Textile groups such as cotton sheeting fabric and cotton poplin exhibited fill rates around 50 percent. The database reveals that the (weighted) average fill rate across all years and exporters for textile groups was only 48 percent compared to 72 percent for apparel groups. These fill rates are consistent with research showing that developed countries apply greater protection to industries where escaping competition from developing countries is harder. Khandelwal (2007), for example, argues that it is harder for developed economies to differentiate their products in terms of quality in apparel versus textiles.

Table 8 also shows that while there is heterogeneity in aggregate fill rates across products, China's fill rates exhibited substantially less variation: in all but one of the ten groups, China's fill rates exceeded 90 percent. Columns three and four report Bangladesh's and India's fill rates in the major groups. Although Bangladesh was bound in the apparel groups, the U.S. did not impose specific limits on Bangladesh in the major textile groups, even 
though Bangladesh exported these products (with the exception of cotton yarns (300/301)). India's fill rates varied widely in the ten groups and was not subject to quotas for underwear, man-made fiber knit shirts and man-made fiber sweaters.

\section{The Relative Restrictiveness of U.S. T\&C Quotas}

In this section we demonstrate the relative restrictiveness of China's quotas in terms of the number of goods subject to quotas, how quickly quotas were allowed to grow and the extent to which China was allowed to shift quota allocations across products and time.

\subsection{Quota Coverage, Fill Rates and ETEs}

The share of a country's MFA groups that are covered by specific limits provides one measure of cross-country variation in quota restrictiveness. Table 7 reports these shares for the major T\&C exporters in the pooled 1990 to 2004 dataset. ${ }^{12}$ As indicated in the table, China, at 61 percent, exhibits the highest share of exports covered by specific limits between 1990 and 2004. Shares for other large Asian exporters are 53 percent for Korea, 51 percent for Taiwan and 46 percent for Hong Kong. By comparison, just 20 percent of India's MFA groups were subject to specific limits.

Fill rates, discussed above, are a second measure of quota restrictiveness. As reported in Table 5, many countries, particularly those in South Asia, exhibited aggregate fill rates over the pooled sample period that are similar to those experienced by China. Fill rates, however, varied substantially over time, as can be seen in Figure 2, which reports the distribution of fill rates for China and three regions - East/Southeast (E/SE) Asia, South Asia and the rest-of-world (ROW) - which, together, comprise all other countries in the sample. ${ }^{13}$ Distributions are reported for three cross-sections, 1985, 1995 and 2004. Each row and column of the figure contains histograms for a different year and region, respectively. In each histogram, the last bin reports the share of binding quotas (i.e., those with fill rates exceeding 90 percent). As indicated in the last three columns of the figure, countries in East/Southeast Asia, South Asia and ROW experienced more-or-less steady declines in binding quotas over the two decades. East/Southeast Asia's binding quotas, for example, drop from 60 percent in 1985 to less than 20 percent in 2004, while the fraction for South Asia decline from 60 and 70 percent in 1985 and 1995, respectively, to 30 percent in $2004 .^{14}$

\footnotetext{
${ }^{12}$ We match the quota data to U.S. import data using a concordance HS-MFA group concordance provided by OTEXA. We have not yet processed the concordance mapping MFA groups to the Tariff Schedule of the U.S. (TSUSA) which would allow an analysis of U.S. T\&C imports for earlier years.

${ }^{13}$ The East/Southeast Asian countries are: Cambodia, Hong Kong, Indonesia, South Korea, Laos, Macau, Malaysia, Philippines, Singapore, Taiwan, Thailand and Vietnam. The South Asian countries are: Bangladesh, India, Maldive Islands, Nepal, Pakistan and Sri Lanka.

${ }^{14}$ The distributions reported in Figure 2 exclude phased-out MFA groups, i.e., the figure displays the distributions of fill rates among quotas still applied to the countries.
} 
China's distribution of fill rates, on the other hand, remained essentially constant over the sample period. This evidence suggest that China's T\&C exports to the U.S. remained relatively constrained throughout the MFA and ATC. China's fraction of binding quotas, coupled with the relatively high extensive-margin constraint described above, provide the first two pieces of evidence that China faced a tighter quota regime compared to other countries.

Andriamananjara et al. (2004) argue that the price wedge created by the quota rents is a better measure of how tightly a quota binds than its fill rate. ${ }^{15}$ The origin of these price wedges and the degree to which they can be observed varies by country. While some countries, such as Hong Kong, created secondary markets to freely trade license permits, others allocated licenses based on various criteria. China's quotas, for example, were managed by its Ministry of Foreign Trade and Economic Cooperation (MOFTEC). MOFTEC auctioned off only a small share of the quotas available under the MFA. The rest were distributed to firms according measures of past performace including: their ability to fill at least 90 percent of their previous quotas; their ability to export other products not subject to constraints; and their ability to improve the quality of their exports (Yang, 1995).

One way to measure the price wedge created by quota rents is to compute quotas' export tax equivalents (ETEs). Under a perfectly competitive T\&C market, the export tax equivalent of a quota depends on the prices of quota licenses,

$$
E T E_{c m t}=\frac{l_{c m t}}{u v_{c m t}-l_{c m t}}
$$

where $l_{c m t}$ is the license price paid by the firm in country $c$ in order to export products in MFA group $m$ at time $t$ (measured in dollars per SME) and $u v_{c m t}$ is the free on board unit value.

We find that fill rates and estimated ETE's are roughly consistent in indicating the extent to which China's exports face a binding quota. Using data on Chinese export license prices available for a subset of MFA groups from 1999 to 2004, we compute the export tax equivalents of U.S. import quotas on Chinese products for these groups. ${ }^{16}$ As indicated in Table 9, which summarizes the results of regressing the log of ETE on MFA group fill rates as well as year fixed effects, fill rates and ETEs are positively correlated. The estimated coefficient is 2.1 and highly significant; it implies that a 10 percentage point increase in the fill rate is associated with a 21 percent rise in the ETE. Column two reports an analogous regression but includes MFA group fixed effects and therefore relies solely on variation within groups to identify the correlation coefficient. As indicated in the table,

\footnotetext{
${ }^{15}$ In countries where export licenses are used to ensure quota adherence, for example, quotas could be binding even if fill rates are low due to insufficient or mis-allocation of licenses. According to Andriamananjara et al. (2004), the internal license allocation regime was inefficient and expensive in many countries.

${ }^{16}$ Data on Chinese export license prices is available at www.chinaquota.com. Unfortunately, similar data is not available for all countries in our sample.
} 
the estimated coefficient is 1.4. These relationships are intuitive: one would expect that firms pay higher license prices for products in which capacity to export is tighter. While license price data is only available for China in select years and MFA groups, we interpret these results as providing support for our and others' use of fill rates as a gauge of quota restrictiveness.

Our results regarding the relative restrictiveness of U.S. import quotas on China compared to its other trading partners are consistent with the more detailed inquiry of Francois and Worz (2006), who estimate ETEs in a gravity-based econometric model that does not require observation of license prices. They find that China's ETEs increased non-linearly under the ATC and estimate China's ETEs in 2002 at 8 percent and 67 percent for Chinese textiles and apparel, respectively. By comparison, they estimate India's ETEs at only 2 percent for textiles and 5 percent for apparel.

\subsection{Quota Growth Rates}

The evolution of countries' fill rates over time implies that quota growth exceeded export growth for all regions except China. Figure 3 traces out the median year-over-year growth in base quota for the four regions over the sample period. For East/Southeast Asia, South Asia and ROW, the step increases in base quota growth rates match the ATC growth-on-growth provision described in Table 1 above. Annual growth for ROW, for example, increased by 16 percent (from 6.00 to 6.96 percent) at the beginning of Phase 1, by 25 percent (to 8.7 percent) at the beginning of Phase II, and by an additional 27 percent (to 11.05 percent) at the beginning of Phase III. The step functions for East and South Asia exhibit identical increases.

China's trajectory of base quota growth, in contrast, is essentially flat. Prior to the ATC, China's growth was roughly equal to that for East/Southeast Asian countries, but in 1994, China's base quota growth was frozen (set to zero). China became eligible for the growth-on-growth provision in 2002, after entry into the WTO, and its median growth rate ticked up slightly, but the magnitude of the increase was small given China's low growth rate. China's overall base growth rate was much lower than the rest of the world for the remainder of the ATC. This restrictiveness also varied across MFA groups. For example, the U.S. imposed slower quota growth for wool products (1 percent for all region in 1995), but even lower growth in these products for China ( 0.5 percent) overall growth.

\subsection{Flexibilities}

The restrictiveness of the U.S. quota regime can also be measured in terms of countries' ability to adjust their base quotas over time. As discussed above, the MFA/ATC agreements granted trading partners limited flexibility to borrow and lend quotas across groups and years in response to demand and supply shocks. To our knowledge, use of flexibilities 
has received little attention in the literature. In this section, we examine both the use of flexibilities as well as their intensity, conditional on use. We find that China's adjustments to its base quotas were more frequent and smaller than those of other countries.

Table 10 demonstrates that China made relatively greater use of flexibilities in terms of frequency than many countries between 1984 and 2004. During this period, China made an adjustment to 92 percent of its quotas. Indeed, a striking feature of the data is that China made at least one adjustment to every quota group between 2000 and 2004.

One potential explanation for China's relatively frequent adjustments is that it faced more restrictive caps on its ability to reallocate quotas across groups and time. If flexibility caps were small, a desired increase in one group might involve more transfers across groups or years than if the caps were large. Unfortunately, the Expired Performance Reports do not provide comprehensive information on countries' flexibility limits over the entire sample period. ${ }^{17}$ Details available for 1997 , however, indicate that China was allowed across-group shifts up to a maximum of 5 percent of the receiving group's base quota and across-time movements of up to 3 percent. Bangladesh and Jamaica, by contrast, were permitted shifts of up to 7 percent across groups and 11 percent across time.

While some countries, notably India and Bangladesh, also made frequent use of the flexibility provisions, among these countries, China faced relatively tighter "flexibility margins" across groups. We define these margins to be the absolute percentage deviation of the adjusted base from the original base for a particular country, group and year. They are computed across all groups in which adjustments are observed. China's median margin, at 5 percent, is the lowest among countries that made adjustments on at least 80 percent of its quota groups. China's margin was also about half the level exhibited by India and Bangladesh.

Another potential explanation for China's greater use of flexibilities was the relative restrictiveness of its quotas. Given the relatively high number of products bound by quotas, their relatively high fill rates, and their relatively low annual growth rates, frequent adjustments to its base levels may have been necessary to respond to given demand or supply shocks. ${ }^{18}$ Countries relatively less constrained by their quota levels and growth rates, by contrast, would have more room to respond without making as many adjustments. Moreover, China's was limited in its ability to shift quotas to respond to these shocks. Though we do not pursue this topic here, it is likely that data on countries' flexibility limits and usage under the MFA/ATC could be used to help construct and calibrate a model of optimal quota borrowing and lending.

\footnotetext{
${ }^{17}$ Flexibilities were capped at an amount determined by the country's bilateral agreement. Unfortunately, we do not have these details for all agreements in the database.

${ }^{18}$ Indeed, Francois and Worz (2006) find that China's ETEs spiked to 25 and 112 percent for textiles and apparel, respectively, in 2004, when China no longer had the ability to carry forward additional quota levels because of imminent end of the MFA/ATC regime.
} 


\section{Quantity Responses to ATC Phase-Outs}

In this section, we examine China and other countries' export quantity responses to the ATC phaseouts. We show that countries' export growth occurred primarily in incumbent products, that it varied according to the relative restrictiveness of China's quotas, and that China's export surge in 2005 had ample precedent in prior phases of quota liberalization.

\subsection{Overview}

Figure 4 provides an overview of U.S. T\&C consumption from 1990 to 2006 according to whether goods were sourced from domestic manufacturers, China, or other U.S. trading partners (ROW). ${ }^{19}$ As indicated in the figure, the contribution of domestic producers and other trading partners rose more-or-less steadily through the 1990s. China's exports, on the other hand, remained relatively flat for the reasons outlined above until 2001. After 2001, China's exports surge, other trading partners' exports begin to level off and U.S. production starts a long-run decline. Between 2000 and 2006, China's total T\&C exports increased almost six-fold from 4.3 billion to 25 billion SME.

To gain a better sense of the potential impact of China's reaction to quota relaxation on other regions' exports, Figure 5 plots the evolution of export quantities by region between 2000 and 2006. Several regions' exports - e.g., North America, the Caribbean and Oceania - end this period lower than they started, with losses for some (e.g., Oceania) being deeper than others. Other regions experienced reversals of robust export growth during the period. Central America's long-running increase in T\&C exports between 2000 and 2005, for example, declined precipitously in 2006. The importance of this reversal is underscored by the fact that T\&C goods accounted for roughly three quarters of Central America's total manufacturing exports to the U.S. in 2004. Similar reversals were experienced by South America, the former Soviet Union, East Asia, the Middle East and Sub-Saharan Africa. For each of these regions, T\&C exports in 2006 were lower than their maximum between 2000 and 2005. South and Southeast Asia, and, although a bit more erratic, the E.U. and North Africa, were the only regions to experience steady export growth between 2000 and 2006.

In the remainder of this section, we provide a more formal assessment of China's impact on other U.S. trading partners T\&C exports to the United States.

\subsection{Intensive vs Extensive Margin Export Growth as Quotas are Removed}

Export growth in response to quota relaxation has two potential sources. The first is net growth within countries' continuing products, i.e., along their "intensive" margin.

\footnotetext{
${ }^{19}$ U.S. production figures are taken from a report of U.S. T\&C production published quarterly by OTEXA (OTEXA, 2007). This publication states that exports at the MFA group level are unreliable, so we set exports to zero to calculate the domestic market size.
} 
The second is net growth due to adding new products or dropping previously exported products, i.e., along their "extensive" margin. ${ }^{20}$ A priori, it is not obvious which margin will dominate; depending upon assumptions, shifting resources into additional product lines may be more profitable than increasing the capacity of existing product lines.

Table 11 decomposes countries' aggregate export quantity growth in percentage terms in the year following each phase of ATC integration. We document export patterns by ATC integration to emphasize the similarities in exporting behavior across each integration stage. Except for China, responses are reported by region. The first column for each phase notes regions' aggregate growth, while the subsequent two columns decompose this aggregate growth into the parts due to countries' intensive and extensive margins. Each panel reports the change in quantities in the year of integration for each phase. That is, panel one reports growth in 1995, panel two in 1998, and so on. Since China became eligible for Phase I and II integration in 2002, the bottom row reports China's response in this year for those phases. As indicated in Table, export growth coinciding with Chinese quota relaxation primarily occurs through the intensive margin. For China, the intensive margin represents more than 90 percent of growth in Phases I, III and IV, and two-thirds of growth in Phase II. Across all other U.S. trading partners, the intensive margin represented the more important margin of adjustment in Phases II-IV.

Table 11 also provides an initial view of the contemporaneous response of China's export growth following each integration phase. China's overall response in the year of each phaseout was 42, 32, 306 and 271 percent for Phases I to IV, respectively. We note that China's Phase III increase accounted for 71 percent of the total increase in Phase III exports in 2002 (i.e., 22 of 31 percentage points). In 2005, aggregate exports from all countries excluding China actually fell 2 percent, a signal that China's impact on other U.S. trading partners was potentially large in this final phase.

\subsection{Reactions to Relaxation of China's Quotas}

Other U.S. trading partners' reaction to the relaxation of China' quotas varied according to their relative restrictiveness. As noted above, we classify China's quotas in the year prior to each phase as being binding if they exhibit a fill rate in excess of 90 percent. ${ }^{21}$ To estimate the differential growth associated with relaxation of bound and unbound quotas, we regress the change in country-products' export quantity on region-year dummies interacted with a dummy variable indicating whether China's quota was previously binding, ${ }^{22}$

$$
\Delta \ln q_{c r h t}=\beta_{1 r t} \text { ChinaBound }_{h, t-1}+\beta_{2 r t} \text { ChinaUnbound }{ }_{h, t-1}+\nu_{c r h t}
$$

\footnotetext{
${ }^{20}$ As noted earlier, the United States imposed quotas at the level of three-digit MFA groups. These groups contain a median of 19 HS products.

${ }^{21}$ Results do not change when we perturb this cutoff.

${ }^{22}$ Because fill rates are available at the MFA group level, we attribute group-level fill rates to all HS products in the group.
} 
where $\Delta \ln q_{c r h t}$ is the change in export quantity of country $c$ in region $r$ in HS product $h$ between years $t$ and $t+1$ and $\beta_{1 r t}$ and $\beta_{2 r t}$ are region-year dummies. These region-year dummies are interacted with ChinaBound ${ }_{h, t-1}$, a dummy variable which equals unity if China's quota in product $h$ in year $t-1$ had a fill rate exceeding 90 percent, and ChinaUnbound ${ }_{h, t-1}$, is a dummy variable which equals one if China was not subject to a binding quota. Vis a vis the aggregate growth pattern displayed in Table 11, this regression differences out the country-product fixed effects. $\beta_{1 r t}$ and $\beta_{2 r t}$ therefore identify the average quantity change across countries in region $r$ within country-products in which China faced binding and nonbinding quotas, respectively. ${ }^{23}$ We focus here on other countries' responses in goods in which China faced non-binding and binding quotas to gain insight into how these regions were influenced by China. Toward that end, the coefficients we report for Phases I to III are for 2002; for Phase IV, we report coefficients for 2005. In line with the results of Table 11, equation 2 concentrates on countries' reactions along the intensive margin.

Table 12 reports OLS estimates for four separate estimations of equation (2), one for each phase of ATC integration. There are two columns for each phase: the first reports countries' average growth in products where China previously faced non-binding quotas $\left(\beta_{2 r t}\right)$, while the second column reports countries' average growth in products where China previously faced binding quotas $\left(\beta_{1 r t}\right)$.

Results for Phase I in the first panel of Table 12 contain all zeros in the binding column because none of China's quotas on Phase I products were binding in 2001. ${ }^{24}$ The second panel reports the 2002 region-year fixed effects for Phase II products. Results in this column indicate that China averaged 153 percent $\left(e^{0.93}-1\right)$ export growth in non-binding products and an incredible 855 percent $\left(e^{2.26}-1\right)$ average increase in bound products. Note that the growth rates for Phase II are higher than the aggregate growth rate reported at the bottom of Table 11; this discrepancy is likely due to the fact that small products grew faster than the large products. ${ }^{25}$ Results for East Asia and South Asia suggest that exports from these regions increased in products where China's quotas were not binding but declined in the products where China faced binding quotas. Results for Phase III show a similar result with respect to China's response, but more muted responses by other countries. China's exports in products subject to binding quotas increased 511 percent compared to 291 percent in unbound products.

\footnotetext{
${ }^{23}$ We exclude the constant in this regression, and standard errors are clustered by exporting country.

${ }^{24}$ Phase I products were placed in the 9xx MFA groups which were a collection of products with which the U.S. was relatively unconcerned and therefore integrated early. The U.S. MFA/ATC Database does not have quota information for these MFA groups. We interpret the fact that this information is missing as evidence that goods in these groups were unconstrained by quotas and this fact was confirmed through correspondences with OTEXA.

${ }^{25}$ See Arkolakis (2007) for a model of market penetration implying that low-volume products grow faster than high-volume products as trade costs fall.
} 
The point estimates for Phase IV are perhaps the most dramatic. Here, too, China's export quantity growth is significantly higher in its bound versus unbound products, 463 percent versus 261 percent. Response to Chinese growth are equally dramatic, with nine of fourteen regions experiencing negative and significant declines in China's bound products. These response contrast starkly with those associated with Phase III.

Variation in countries' reactions to the removal of Chinese quotas likely reflects differences in comparative advantage across T\&C products. Though formal assessment of countries' elasticities of substitution with Chinese exports requires structural estimation beyond the scope of this chapter, the results in Table 12 can be used to provide a rough guide as to which countries were the biggest "losers" with respect to China. Toward that end, Table 13 reports the results of a Phase IV regression like that in equation 2 but at the country level. Countries are ordered according to their average response in China's previously bound products, with statistically significant responses in bold. Of the 143 countries in the table, average exports fell in 102 countries, and these drops were statistically significant for 54 countries. Statistically significant declines range from a low of 13 percent $\left(e^{0.14}-1\right)$ for Italy to a high of more than 80 percent for Kuwait, Russia, the Maldives, Micronesia, Guinea and Oman. Remarkably, only eight countries exhibit an increase in exports. Three of the largest South Asian exporters - Bangladesh, India and Pakistan - report positive but statistically insignificant changes in exports. Though these countries fare much better than others, it is possible their export growth might have been much higher in the absence of robust Chinese growth.

Declines among Sub-Saharan African exporters may have been particularly economically significant. These countries experienced increasing T\&C exports to the United States from 2000 to 2004 because of modifications made to the rules-of-origin requirements under AGOA; as shown in Figure 5, the region's T\&C exports doubled between 2000 and 2004. These modifications - collectively referred to as the "Special Rule"-allowed countries to satisfy rules-of-origin requirements using fabric of any origin provided that the clothing assembly took place within the countries' borders. As discussed in Whalley and Dayaratna-Banda (2007), firms responded to the Special Rule by importing fabrics from Asian countries for assembly in Africa. ${ }^{26}$ The Special Rule also lead to substantial inward foreign direct investment as multinational firms located the final stages of production in Africa to "hop" over quotas (Frazer and Van Biesebroeck, 2007). These responses contributed to a boom in SubSaharan T\&C production, particularly in Madagascar, Lesotho and Swaziland. Between 2000 and 2004, for example, Lesotho's T\&C exports to the United States nearly quadrupled, to $\$ 455$ million, as the number of T\&C factories located in the country doubled from 21 to 47 (IMF 2007). In the year following the end of the ATC in 2005, however, Lesotho's

\footnotetext{
${ }^{26}$ The following AGOA countries were not eligible for the Special Rule provision: Botswana, Gabon, Mauritius, Namibia, Seychelles, and South Africa (www.agao.gov).
} 
$\mathrm{T} \& \mathrm{C}$ production shrank considerably. ${ }^{27}$ Both the value and quantity of its T\&C exports to the United States fell 14 percent; in China's bound products, the average Lesotho export fell 43 percent. These declines were accompanied by a 30 percent fall in employment, to 35,000 workers, and one quarter of its production facilities being shuttered (IMF 2007).

The most plausible explanation for the sharp decline in Sub-Saharan T\&C production following the end of the ATC (and, therefore, the end of the Special Rule's value) is that African production costs are prohibitive, either because relatively low wages are in fact relatively high in quality- or productivity-adjusted terms or because transport costs make multi-national production absent an extra inducement infeasible. Further research into the reasons behind this decline would be useful both for evaluating appropriate policy responses and for understanding the dynamics of Sub-Saharan African economies.

\section{Price Responses to ATC Phaseouts}

A second margin along which countries might react to the removal of import quotas is price. In this section we examine the evolution of the United States' T\&C import free-onboard unit values (i.e., import value per SME) subsequent to each Phase of ATC integration. In contrast to the results reported above, we here focus on countries' unit value changes in response to their own, not China's, quota relaxations.

Table 14 reports the results of a regression similar to equation (2) but where the dependent variable is the log difference in unit value rather than export quantity, and where the binding dummy takes a value of one if the country-product was constrained in its country of origin the prior year. As a result, coefficient estimates are with respect to 1995, 1998, 2002 and 2005 for Phases I through IV, respectively in the upper portion of the table. China's response to its Phase I and II good quota relaxations in the year in which those quotas were actually removed (i.e., 2002) are reported at the bottom of the table.

As indicated in Table 14, China's average unit values fell in the years that its products were integrated. Here, as above, responses varied according to whether or not China faced binding quotas. Unit value declines for exports previously restrained by China's binding quotas were larger in all integration phases. In 2002, Chinese unit values for bound Phase II products fell 55 percent $\left(e^{-0.81}-1\right)$ versus 32 percent for unbound products. For Phase III and IV products, the declines for China were 48 versus 42 percent, and 41 versus 31 percent, respectively. More broadly, though unit value responses vary across phases, they are generally negative and significant for East Asia, Southeast Asia and South Asia, and generally larger in bound products than unbound products.

One explanation for China's and other countries' unit value declines is simply that as quotas are relaxed, goods prices decline and firms slide down their demand curves as prices

\footnotetext{
${ }^{27}$ As noted by Whalley and Dayaratna-Banda (2007), Sub-Saharan T\&C exports in 2005 were also hurt by an appreciation of the South African Rand.
} 
and quantities adjust to the previously unrealizable competitive outcome. Indeed, Francois and Worz (2006) estimate the export tax equivalent of Chinese quotas to be 25 percent for textiles and 110 percent for apparel in 2004. With the quotas removed, ETEs, by definition, fall to zero.

Declining prices might also accompany quota relaxation as a result of quality downgrading. It is well known in the international trade literature that firms facing quotas have an incentive to export higher-margin goods; see, for example, the theoretical research of $\mathrm{Kr}$ ishna (1987) and Das and Donnenfeld (1987) and the empirical studies of Aw and Roberts (1986) and Feenstra (1988). Evans and Harrigan (2005), for example, find that U.S. imports of products facing binding quotas exhibit a 6.3 percent price premium relative to unbound imports. Under the assumption that prices reflect only vertical product differentiation, the results reported in Table 14 provide prima facie evidence that China's T\&C quality fell following the removal of quotas.

Quality upgrading in response to quantitative restrictions is possible through changes in demand or changes in supply-side characteristics. In the former, imposition of quota rents leads to identical markups across products which induce consumers to substitute towards higher-priced varieties. This effect is similar to Alchian and Allen's (1964) Washington apples story where higher-priced goods are shipped over greater distances to lower the per dollar transport costs (see also Hummels and Skiba 2004). Feenstra and Boorstein (1994) infer quality in this context by comparing a unit value index, which uses quantity weights, to an exact price index, which uses value weights: if the unit value index increases by more than the exact price index, consumption has shifted towards more expensive goods and average quality of goods from the restricted country increases. Using this method to study the affects of quota removal, Harrigan and Barrows (2007) find that the quality of China's bound products fell 7 percent more than its unbound products when quotas were removed in 2005.

Here, we complement Harrigan and Barrows (2007) by using an approach developed in Khandelwal (2007) to measure quality changes within countries' products. As discussed in detail in the Appendix, this approach uses a discrete choice demand system to infer countryproduct (i.e., variety) quality, relative to the average U.S. domestic quality, by estimating differences in relative market shares after controlling for prices. We then examine how these measures of country-product quality react to quota removal using a specification analogous to the ones employed above,

$$
\Delta \theta_{\text {cht }}=\beta_{1 r t} \text { ChinaBound }_{h, t-1}+\beta_{2 r t} \text { ChinaUnbound }_{h, t-1}+\nu_{\text {crht }} .
$$

where $\theta_{\text {cht }}$ is the estimated quality of country $c$ in product $h$ at time $t$ obtained from a implementing the approach discussed in the Appendix. In this specification, we regress the change in country-product quality on region-year fixed effects which are interacted with 
ChinaBound $_{h, t-1}$, a dummy variable which equals unity if China's quota in product $h$ in year $t-1$ had a fill rate exceeding 90 percent, and ChinaUnbound $d_{h, t-1}$, is a dummy variable which equals one if China was not subject to a binding quota. To focus attention on China, we estimate a single ROW fixed effect for each year for all other countries and, as before, run the regressions separately by phase. For Phases I and II, we report coefficients for 2002 when China became eligible for integration, rather than the phaseout defined under the ATC. Coefficients and standard errors are reported in Table 15.

The coefficients generally report a positive change in quality in the year of integration for both bound and unbound varieties and for both China and the ROW. On first inspection, these results appear inconsistent with the idea that dismantling quotas results in quality downgrading. Recall, however, that our measure of country-product quality reflects consumers' valuation of Chinese goods relative to "outside goods," which, in this case, are domestic varieties. These relative valuations complicate the evaluation of the results in Table 15 because, for example, a deterioration in the quality of the outside good would lead to increase in the quality of the imported varieties. That is, our measure of quality does not separately identify shifts in preferences across HS products versus shifts in preferences towards the outside good. ${ }^{28}$

We can use the coefficients in reported in Table 15 to compute a difference-in-differences estimate of China quality upgrading in bound products that uses quality change in unbound products and the ROW as baselines. ${ }^{29}$ First, we first take the difference between China's change in quality for bound and unbounded varieties; for Phase IV this is 0.72-1.01, or -0.29. This first difference controls for country-specific changes in technology or shifts in demand that are common to all varieties within the country. Second, we compare this difference to the analogous difference in the ROW's coefficients for China's bound and unbound products; for Phase IV this is $-0.29-0.18$, or -0.47 . This second difference nets out changes in consumers' valuation across varieties. For example, suppose there is a positive technology shock to the Chinese T\&C industry. The first difference would control for the technology shock since the shock would be common to China's bound and unbound exports. Now suppose an extreme winter increases the demand winter clothing; this shock, common to both China and ROW assuming away compositional differences, is controlled by differencing Chinese quality with the ROW within products. In this way, the differencein-differences estimate provides an uncontaminated estimate of the relative Chinese boundversus-unbound quality change following each phase-out.

\footnotetext{
${ }^{28}$ See Nevo (2003) for a detailed discussion on this point. We note that the quality levels could be biased upwards if measurement error in the prices leads to attenuation bias in $\alpha$. Assuming that the attenuation bias is the same in bound and unbound products, this possibility provides further motivation for computing difference-in-differences estimates. Problems associated with measurement error are also mitigated by our use of trade costs as an instrument for price.

${ }^{29}$ Actually, this is a triple difference specification, but since we focus on changes in quality, the time difference is already assumed.
} 
Difference-in-difference estimates for each Phase are reported in the bottom panel of Table 15. As mentioned earlier, China's Phase I products were not subject to binding quotas, so we merely report the difference between China's and the ROW's unbound quality changes, which is positive and significant at the ten percent level. For Phase II, we find that China's bound products actually increase in quality, an outcome that is inconsistent with theory. One possible explanation for this result is that Phase II products were only marginally binding in a way that our assessment of bindingness does not pick up.

We do find relative declines in China's bound products' quality in response to Phases III and IV, though only the latter estimate is statistically significant at conventional levels. In both Phases, China registered improvements in quality within bound and unbound varieties, but ROW quality increases by more. These results appear consistent with theory and complement the across-good shifts in demand identified by Harrigan and Barrows (2006) for Phase IV products. They also support the idea that restrictions on China were relatively more stringent.

\section{China's T\&C Future}

China's share of U.S. textile and clothing imports jumped three-fold, from 10 to 33 percent, between the time it joined the WTO in December 2001 and the end of the ATC regime in 2005. This growth, and in particular China's surging exports in the early months of 2005, spurred domestic firms and other developing countries to lobby the United States, successfully, for the re-imposition of textile and clothing quotas on China. By the middle of 2005, the U.S. and China had agreed to new limits on China's exports in a subset of T\&C categories previously covered by Phase IV of the ATC. These categories are listed in Table 2; they are to remain in effect until 2008.

Some analysts believe that China's large increase in Phase IV exports in early 2005 occurred primarily as a hedge against future protectionist measures. By dramatically increasing their exports early in the year, this line of thinking goes, Chinese firms would be able to establish higher base levels for an inevitable new round of quotas. Table 2 provides some evidence in favor of this hypothesis, as the new, post-ATC quota levels agreed to in 2005 were substantially larger than the levels previously imposed by the ATC. Going forward, it is not clear that China will be free of quotas after 2008. According to its WTO accession documents, WTO member countries are allowed to impose product-specific safeguards on China to prevent market disruptions until 2013. As a result, the U.S. might continue to apply quotas or resort to other forms of protection, such as anti-dumping remedies, once the current safeguards are removed (Bown, 2007). Whalley and Dayaratna-Banda (2007) argue that the new safeguards are merely a means of re-imposing an MFA/ATC regime on China, with the major exception that quotas now just apply to China as opposed to all developing economies. 
China's exports to the EU also surged after ATC expired. This increase induced a similar response in the EU, with the result that China and the EU also signed a new bilateral agreement in 2005 restricting China's imports in 10 groups of T\&C products through $2007 .{ }^{30}$ As was well reported at the time, China satisfied its quotas in these goods by September 2005 , with the result that $\$ 501$ million worth of Chinese goods backed up on European ports. ${ }^{31}$ Only after high-level negotiations led to an amended quota agreement for 2005 were these goods allowed into the EU. The EU's new safeguards remain in effectuntil December 31, 2007; they are summarized in Table 16.

Many observers have reacted to China's T\&C export growth with the claim that all of the world's T\&C production will relocate to China once its quotas are abolished permanently. Interestingly, Chinese officials appear to be looking beyond their dominance of apparel and textiles, and have voiced concern that rising wages will erode their comparative advantage in this sector vis a vis even lower-wage countries like Vietnam, Cambodia and Bangladesh. ${ }^{32}$ Though such an outcome appears unlikely, at least in the near term, these countries have become more important sources of $\mathrm{T} \& \mathrm{C}$ exports in recent years. In the year after its trade relations with the U.S. were normalized in 2001, for example, Vietnam's T\&C exports to the U.S. increased 240 percent, though its market share in terms of quantity in 2005 remained under 2 percent. Until 2007, when it, too joined the WTO, Vietnam's exports were hampered by U.S. quotas on 25 groups of T\&C products.

Given the large T\&C export capacity of China, China's dominance of the T\&C market should continue into the near future, especially as the new safeguards expire. As China continues its transition towards more capital- and and skill-intensive industries, however, it is likely that the relative importnace of apparel and textiles in the Chinese economy will fall. Already, T\&C exports have declined to 11 percent of the country's total exports to the U.S., down from 26 percent in 1990. As this transition continues, it is likely that countries at earlier stages of development, such as Cambodia and Vietman, will become bigger players.

\section{Appendix: Quality Estimation}

This Appendix explains how to identify quality from the T\&C import data. The framework is based on the approach taken by Khandelwal (2007) and the reader is referred to that paper for additional details.

We assume that consumers have discrete choice preferences and select the one countryproduct variety that provides them with the highest utility. The (indirect) utility that

\footnotetext{
${ }^{30}$ Dayaratna-Banda and Whalley (2007) report that China has either signed, or is in negotiations to sign, similar quota agreements with Brazil, Turkey, Canada, Mexico and Peru.

31 "Europe and China in Accord Over End to a Textile Dispute,"New York Times, September 6, 2005.

${ }^{32}$ See the discussions of the 2007 China Development Forum, "Towards New Models of Economic Growth", available at http://www.cdrf.org.cn/en/.
} 
consumer obtains from purchasing variety $c h$ is

$$
V_{c h n t}=\theta_{1 c h}+\theta_{2 t}+\xi_{c h t}-\alpha p_{c h t}+\varepsilon_{c h n t},
$$

where $\theta_{c h}+\theta_{t}+\xi_{c h t}$ denotes the quality of variety $c h$ at time $t, p_{c h t}$ denotes its price and $\varepsilon_{\text {chnt }}$ is a random consumer-variety specific term. The random term $\varepsilon$ introduces horizontal differentiation; its inclusion precludes prices from being sufficient statistics for quality. ${ }^{33}$ The random term $\varepsilon$ can be decomposed into two randomly distributed components,

$$
\varepsilon_{c h n t}=\psi_{h n t}+(1-\sigma) \nu_{c h n t}
$$

with $0 \leq \sigma<1$. The $\psi$ term is a consumer-HS product random effect which provides consumer $n$ with an idiosyncratic utility from choosing a variety that resides in product $h$. This term generates a nested logit system which is a more flexibility demand model because

it alleviates the IIA problem found in simple logit models. The product-level random effect creates correlation across varieties within a same HS code which means that consumers are more likely to substitute towards varieties within the same product. ${ }^{34}$

Under the assumption that $\nu$ is an i.i.d extreme value, we can aggregate over all individual purchases in the economy to obtain aggregate market shares for each variety (e.g., see Berry 1994). In order to complete the demand system, the consumer is allowed to choose an "outside" good if none of the inside varieties provides him with a high enough utility. In this context, the outside good market share is the U.S. market share.

The aggregation leads to the following demand system equation

$$
\ln s_{c h t}-\ln s_{0 t}=\theta_{1 c h}+\theta_{2 t}-\alpha p_{c h t}+\sigma \ln s_{c \mid h t}+\xi_{c h t}
$$

The left hand side of the demand system measures the variety's market share $s_{\text {cht }}$ relative to the outside good market share $\left(s_{0 t}\right)$. We run regression (6) separately for aggregates of the MFA groups. ${ }^{35}$ This allows price sensitivities and year fixed effects to vary by aggregate leading to more flexible parameter estimates. The portion of observed quality are captured by country-product $\left(\theta_{1 c h}\right)$ and year $\left(\theta_{2 t}\right)$ fixed effects. The price is denoted by $p_{c h t}$ where $\alpha$ captures price sensitivity (a semi-elasticity). The $s_{c \mid h t}$ term results from the demand structure that nests varieties within products. This term captures the variety's market

\footnotetext{
${ }^{33}$ In a vertical market, prices are sufficient statistics for quality. Here, a variety that happens to possess a low quality, $\theta_{c h}$, and a high price, $p_{c h t}$, may still be purchased if the consumer draws a high $\varepsilon_{c h n t}$.

${ }^{34}$ As $\sigma$ goes to zero, the within product correlation also goes to zero and the model converges to a standard logit model.

${ }^{35}$ Market share within an MFA group sum to one, but we pool observations over aggregates of the MFA groups. For example, one aggregate includes dresses which differ according to fabric (e.g., MFA groups 336, 436, 636, 736, and 836). MFA groups are classified into 43 aggregates.
} 
share within product $h$ at time $t$. Finally, $\xi_{c h t}$ is the unobserved component of quality that becomes the residual of the estimating equation. Since this term is potentially correlated with prices, we have the classic simultaneity problem associated with estimating demand curves. We identify the equation by instrumenting price with trade costs. ${ }^{36}$ The estimated qualities are defined by $\theta_{c h t}=\theta_{1 c h}+\theta_{2 t}+\xi_{c h t}$. The interpretation of these quality measures is that conditional on price, the variety with higher market shares have higher quality. ${ }^{37}$

\section{References}

\section{References}

Alchian, A. and W. Allen (1964). University Economics. Belmont, CA: Wadsworth.

Andriamananjara, S., J. Dean, and D. Spinanger (2004). Trade apparel: Developing countries in 2005. Kiel Institute of World Economics.

Arkolakis, C. (2007). Market Access Costs and the New Consumers Margin in International Trade. Mimeo, Yale University.

Aw, B. Y. and M. Roberts (1986). Measuring quality change in quota-constrained import markets. Journal of International Economics 21, 45- 60.

Berry, S. (1994). Estimating Discrete-Choice Models of Product Differentiation. RAND Journal of Economics 25, 242-262.

Berry, S., J. Levinsohn, and A. Pakes (1995). Automobile Prices in Market Equilibrium. Econometrica 63, 841-890.

Boorstein, R. And R. Feenstra (1991). Quality Upgrading and Its Welfare Costs in U.S. Steel Imports, 1969-1974, in E. Helpman and A. Razzin, eds. International Trade and Trade Policy. Cambridge: MIT Press, 1991, 157-186.

Bown, C. (2007). China's WTO Entry: Antidumping, Safeguards and Dispute Settlement. NBER Working Paper No. 13349.

Das, S. and S. Donnenfeld (1987). Trade policy and its impact on quality of imports: A welfare analysis. Journal of International Economics 23, 77-95.

\footnotetext{
${ }^{36}$ Hummels and Skiba (2004) find evidence supporting the Alchian-Allen conjecture that export quality increases with trade costs. This potentially raises concerns that trade costs may be correlated with variety quality. However, the exclusion restriction remains valid as long as transport costs affect average quality and not the time-specific deviation, $\xi_{c h t}$. Since the nest share term is also endogenous, we use the number of varieties within HS product to instrument this term (Berry et al., 1995)

${ }^{37}$ Note that this intuition for quality is similar to that found in Hallak and Schott (2007). The results of these regressions are available upon request.
} 
Dayaratna-Banda, O. and J. Whalley (2007). After the MFA, the CCAs (China Containment Arrangments). CIGI Working Paper No. 24.

Diao, X. and A. Somwaru (2001). Impact of the MFA phase-out on the world economy an intertemporal, gobal general equilibrium analysis. TMD Discussion Paper No. 79.

Evans, C. and J. Harrigan (2005). Tight clothing: How the MFA affects apparel exports. In T. Ito and A. Rose (Eds.), International Trade in East Asia. Chicago: The University of Chicago Press.

Feenstra, R. (1988). Quality change under trade restraints in Japanese autos. Quarterly Journal of Economics 103, 131-146.

Francois, J. and J. Worz (2006). Rags in the High Rent District: The Evolution of Quota Rents in Textiles and Clothing. CEPR Working Paper 5477.

Frazer, G. and J. Van Biesebroeck (2007). Trade Growth Under the African Growth and Opportunity Act. NBER Working Paper 13222.

Hallak, J. and P. Schott (2007). Estimating cross-country differences in product quality. Yale University, Mimeo.

Harrigan, J. and G. Barrows (2006). Testing the theory of trade policy: Evidence from the abrupt end of the Multifibre Arrangement. NBER Working Paper 12579.

Hummels, D. and A. Skiba (2004). Shipping the Good Apples Out? An Empirical Confirmation of the Alchian-Allen Conjecture. Journal of Political Economy. 12(6), 1384-1402.

IMF (2007). End of Quotas Hits African Textiles. IMF Survey Magazine: In the News, July $5,2007$.

Khandelwal, A. (2007). The long and short (of) quality ladders. Yale University, Mimeo.

Krishna, K. (1987). Tariffs versus quotas with endogenous quality. Journal of International Economics 23, 97-112.

Nevo, A. (2003). New Products, Quality Changes and Welfare Masures Computed from Estimated Demand Systems. The Review of Economics and Statistics, 85(2), 266-275.

Nordas, H. (2004). The global textile and clothing industry post the agreement on textiles and clothing. WTO discussion Paper 5.

Rivera, S., L. Agama and J. Dean (2003). Africa beyond 2005: Understanding the impact of eliminating NTBs and tariffs on textiles and clothing. International Trade Commission, mimeo. 
Schott, P. (2008). The relative sophistication of Chinese exports. Economic Policy 53, 5-49.

Spinanger, D. (1999). Texiles beyond the MFA phase-out. World Economy 22, 455 - 476.

USITC (2004). Textile and apparel: Assessment of the competitiveness of certain foreign suppliers to the U.S. market. Investigation No. 332-448.

Whalley, J. and O. Dayaratna-Banda (2007). After the MFA, the CCAs (China Containment Agreements). CIGI Working Paper No. 24.

World Trade Organization (2001). Report of the working party on the accession of china. $W T / A C C / C H N / 49$.

Yang, Y. (1995). China's textile and clothing exports: Challenges in the post-MFA period. Pacific Economic Papers 250, 6.7-6.12. 


\begin{tabular}{ccccc} 
Phase & Starting Date & $\begin{array}{c}\text { Share of Export } \\
\text { Volume Integrated }\end{array}$ & $\begin{array}{c}\text { Increase in Quota } \\
\text { Growth Rate }\end{array}$ & $\begin{array}{c}\text { Number of HS } \\
\text { Products Integrated }\end{array}$ \\
\hline I & January 1, 1995 & 16 & 16 & 318 \\
II & January 1, 1998 & 17 & 25 & 744 \\
III & January 1, 2002 & 18 & 27 & 745 \\
IV & January 1, 2005 & 49 & n/a & 2,978 \\
\hline \hline
\end{tabular}

Notes: Table describes the four phases of the Agreement on Textiles and Quotas. First three columns describe aspects of the Agreement that were common to all signatories. Final column reports the integration of products as implemented by the United States. Quota growth acceleration was advanced one phase for countries with less than 1.2 percent of the importing country's total quotas in 1991. Source: OTEXA.

Table 1: ATC Integration Schedule 


\begin{tabular}{|c|c|c|c|c|c|c|}
\hline MFA Category & Unit & 2004 Quota & 2005 Exports & 2006 Quota & 2007 Quota & 2008 Quota \\
\hline 200 Yarns and sewing thread ${ }^{a}$ & KG & 939,116 & na & na & na & na \\
\hline 300/301 Carded and combed cotton yarn ${ }^{a}$ & KG & $2,671,428$ & na & na & na & na \\
\hline $200 / 301^{\mathrm{a}}$ & KG & - & $6,949,753$ & $7,529,582$ & $8,832,199$ & $10,131,052$ \\
\hline 222 Knit fabric & KG & $10,619,328$ & $18,145,812$ & $15,966,487$ & $18,728,689$ & $21,482,908$ \\
\hline 229 Special purporse fabric $^{\text {b }}$ & KG & - & $29,001,226$ & $33,162,019$ & $39,237,301$ & $45,007,492$ \\
\hline $332 / 432 / 632$ Hosiery $^{c}$ & DPR & $42,433,990$ & $58,230,777$ & na & na & na \\
\hline $332 / 432 / 632-B$ Baby socks ${ }^{c}$ & DPR & - & - & $61,146,461$ & $71,724,800$ & $80,866,195$ \\
\hline $332 / 432 / 632-\mathrm{T}$ Baby socks ${ }^{\mathrm{c}}$ & DPR & - & - & $64,386,841$ & $75,443,136$ & $85,058,437$ \\
\hline 338/339 Cotton knitted shirts \& blouses & $\mathrm{DOZ}$ & $2,523,532$ & $20,624,490$ & $20,822,111$ & $23,893,373$ & $26,938,606$ \\
\hline $340 / 640$ Men's and boys' woven shirts & $\mathrm{DOZ}$ & $2,345,946$ & $6,173,242$ & $6,743,644$ & $7,738,332$ & $8,724,590$ \\
\hline $345 / 645 / 646$ Sweaters & $\mathrm{DOZ}$ & $1,030,348$ & $7,850,557$ & $8,179,211$ & $9,477,660$ & $10,581,854$ \\
\hline $347 / 348$ Cotton trousers & $\mathrm{DOZ}$ & $2,421,922$ & $18,379,851$ & $19,666,049$ & $22,566,791$ & $25,442,951$ \\
\hline 349/649 Brassieres & $\mathrm{DOZ}$ & $17,729,479$ & $20,717,107$ & $22,785,906$ & $26,146,827$ & $29,479,266$ \\
\hline 352/652 Underwear & $\mathrm{DOZ}$ & $5,276,745$ & $18,175,964$ & $18,948,937$ & $21,957,081$ & $24,302,011$ \\
\hline 359-S/659-S Swimwear & KG & 750,959 & $5,951,219$ & $4,590,626$ & $5,267,743$ & $5,990,767$ \\
\hline 363 Cotton terry towels & NO & $24,773,109$ & $87,842,008$ & $103,300,000$ & $118,600,000$ & $134,828,519$ \\
\hline 443 Men's \& boys' wool suits & NO & 140,015 & $1,613,356$ & $1,346,082$ & $1,544,629$ & $1,756,637$ \\
\hline 447 Men's \& boys' wool trousers & $\mathrm{DOZ}$ & 76,352 & 203,332 & 215,004 & 246,718 & 280,581 \\
\hline 619 Polyester filament fabric ${ }^{\mathrm{D}}$ & M2 & - & $60,348,016$ & $55,308,506$ & $63,466,510$ & $72,177,600$ \\
\hline 620 Other synthetic filament fabric $^{b}$ & M2 & - & $83,531,558$ & $80,197,248$ & $92,026,342$ & $103,755,190$ \\
\hline 622 Glass fabric $^{\mathrm{b}}$ & M2 & - & $30,274,778$ & $32,265,013$ & $37,846,860$ & $43,412,575$ \\
\hline $638 / 639$ MMF knitted shirts \& blouses & $\mathrm{DOZ}$ & $2,712,680$ & $3,762,225$ & $8,060,063$ & $9,248,922$ & $10,427,707$ \\
\hline $647 / 648 \mathrm{MMF}$ trousers & $\mathrm{DOZ}$ & $2,974,238$ & $6,490,061$ & $7,960,355$ & $9,134,507$ & $10,298,709$ \\
\hline 666 Window blinds/window shades & KG & 573,372 & 0 & 964,014 & $1,106,206$ & $1,268,884$ \\
\hline 847 Silk blend \& other vegetable fibre trousers ${ }^{D}$ & $\mathrm{DOZ}$ & - & $15,714,461$ & $17,647,255$ & $20,250,225$ & $23,029,668$ \\
\hline
\end{tabular}

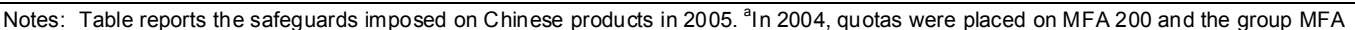
300/301. In 2006, quotas were reimposed on MFA 200 and MFA 301 to reflect a new group category, MFA 200/301. Using the footnotes in the OTEXA expired performance reports, we aggregated 2005 exports to reflect this new group and denote 2005-08 exports and quotas with in 200 and 300/301 with a "na". ' No specific limit quotas in 2004. 'In 2004, quotas were applied on MFA group 332/432/632, and in 2006, quotas were imposed on two new group categories, 332/432/632-B and 332/432/632-T. We were unable determine if the quota levels for these two new MFA groups reflect an aggregate quota or not, so we report the 2006-08 figures for 332/432/632-B and 332/432/632-T as reported in the official OTEXA documents, and denote 2006-08 quotas for 332/432/632 with a "na". For 2005 exports, we aggregate the exports from MFA 332,432 , and 632 using the trade data and the HS-MFA concordance described in the text. Source: Authors' calculations from the trade data and OTEXA. Source: OTEXA and authors' calculations.

Table 2: Chinese Quotas under Safeguards, 2006-2008 


\begin{tabular}{|c|c|c|c|c|}
\hline Argentina & Dominican Republic & Kenya & Oman & Sri Lanka \\
\hline Bahrain & Egypt & Korea, South & ${ }^{*}$ Pacific Islands & Taiwan \\
\hline Bangladesh & El Salvador & Kuwait & Pakistan & Thailand \\
\hline *Barbados & Fiji & Laos & Panama & ${ }^{*}$ Trinidad Tobago \\
\hline Belarus & Germany, East & *Lebanon & Peru & Turkey \\
\hline Brazil & Guam & Lesotho & Philippines & UAE \\
\hline Bulgaria & Guatemala & Macau & Poland & Ukraine \\
\hline Burma & Haiti & Macedonia & ${ }^{*}$ Portugal & Uruguay \\
\hline Cambodia & Honduras & Malaysia & Qatar & USSR \\
\hline${ }^{*}$ Canada & Hong Kong & Maldive Islands & Romania & Vietnam \\
\hline China & Hungary & Mauritius & Russia & Yugoslavia \\
\hline Colombia & India & Mexico & Singapore & \\
\hline Costa Rica & Indonesia & Nepal & Slovak Republic & \\
\hline Czech Republic & Jamaica & Nigeria & South Africa & \\
\hline Czechoslovakia & Japan & Northern Mariana & *Spain & \\
\hline
\end{tabular}

Table 3: List of Countries in U.S. MFA/ATC Database 


\begin{tabular}{lccc} 
MFA Group Description & Segment & Units & $\begin{array}{c}\text { Square Meter } \\
\text { Conversion }\end{array}$ \\
\hline 218 Yarns of different colors (cotton \&/or mmf) & Yarn & SQM & 1 \\
219 Duck fabric (cotton \&/or mmf) & Yarn & SQM & 1 \\
606 Non-textured filament yarn (mmf) & Yarn & KG & 20.1 \\
621 Impression fabric (mmf) & Fabric & KG & 14.4 \\
628 Twills/sateens staple/filament fiber (mmf) & Fabric & SQM & 1 \\
629 Other fabrics of staple/filament fiber (mmf) & Fabric & SQM & 1 \\
348 W\&G trousers, breeches \& shorts (cotton) & Apparel & DOZ & 14.9 \\
350 Robes, dressing gowns, etc. (cotton) & Apparel & DOZ & 42.6 \\
431 Gloves and mittens (wool) & Apparel & DPR & 1.8 \\
433 M\&B suit-type coats (wool) & Apparel & DOZ & 30.1 \\
836 Dresses (silk or non-cotton veg. fibers) & Apparel & DOZ & 37.9 \\
362 Bedspreads \& quilts (cotton) & Made-ups & NO & 5.8 \\
464 Blankets (wool) & Made-ups & KG & 2.4 \\
465 Floor coverings (wool) & Made-ups & SQM & 1 \\
665 Floor coverings (mmf) & Made-ups & SQM & 1 \\
\hline \hline Notes: Examples of MFA groups, native units and the conversion factors to square \\
meters. Source: U.S. MFA/ATC Database. & & &
\end{tabular}

Table 4: Sample OTEXA Category Descriptions 


\begin{tabular}{|c|c|c|c|}
\hline Country & $\begin{array}{c}\text { Adjusted } \\
\text { Base Quota } \\
\text { (SME) }\end{array}$ & $\begin{array}{l}\text { Export } \\
\text { (SME) }\end{array}$ & $\begin{array}{c}\text { Fill Rate } \\
(\%)\end{array}$ \\
\hline China & 28.4 & 24.9 & 88 \\
\hline Taiwan & 26.3 & 16.6 & 63 \\
\hline Hong Kong & 22.8 & 17.1 & 75 \\
\hline Korea, South & 21.3 & 13.3 & 63 \\
\hline Turkey & 13.0 & 5.7 & 44 \\
\hline Pakistan & 12.4 & 10.3 & 84 \\
\hline Malaysia & 11.0 & 3.8 & 35 \\
\hline Thailand & 11.0 & 6.9 & 63 \\
\hline Indonesia & 10.3 & 8.8 & 85 \\
\hline Philippines & 9.6 & 6.9 & 72 \\
\hline India & 8.4 & 7.3 & 87 \\
\hline Bangladesh & 8.0 & 7.0 & 88 \\
\hline Egypt & 7.1 & 1.9 & 27 \\
\hline Brazil & 6.9 & 2.4 & 35 \\
\hline Sri Lanka & 5.4 & 4.4 & 81 \\
\hline Singapore & 3.8 & 1.6 & 43 \\
\hline Mexico & 3.0 & 1.2 & 39 \\
\hline Macau & 2.8 & 1.9 & 69 \\
\hline Dominican Republic & 2.6 & 1.7 & 66 \\
\hline Romania & 1.9 & 0.4 & 21 \\
\hline UAE & 1.8 & 1.1 & 60 \\
\hline Japan & 1.6 & 1.0 & 61 \\
\hline Jamaica & 1.5 & 0.3 & 20 \\
\hline Colombia & 1.5 & 0.2 & 10 \\
\hline Honduras & 1.3 & 0.3 & 25 \\
\hline Mauritius & 1.1 & 0.5 & 44 \\
\hline Costa Rica & 1.1 & 0.6 & 51 \\
\hline Guatemala & 0.9 & 0.7 & 73 \\
\hline Poland & 0.9 & 0.1 & 13 \\
\hline Cambodia & 0.9 & 0.8 & 85 \\
\hline
\end{tabular}

Table 5: Total Specific Limit Base, Top 30 Countries 
Binding Quotas -

Binding Quotas - Binding Quotas - Conservative Definition

\begin{tabular}{|c|c|c|c|}
\hline Country & Liberal Definition (\%) & Default Definition (\%) & $(\%)$ \\
\hline Bangladesh & 89 & 81 & 75 \\
\hline India & 76 & 65 & 57 \\
\hline China & 72 & 64 & 55 \\
\hline Indonesia & 73 & 59 & 50 \\
\hline Pakistan & 67 & 57 & 47 \\
\hline Guatemala & 67 & 45 & 32 \\
\hline Hong Kong & 52 & 42 & 34 \\
\hline Macau & 52 & 41 & 32 \\
\hline UAE & 48 & 39 & 28 \\
\hline Philippines & 53 & 37 & 30 \\
\hline Sri Lanka & 50 & 36 & 27 \\
\hline Thailand & 51 & 36 & 25 \\
\hline Cambodia & 42 & 32 & 28 \\
\hline Korea, South & 42 & 30 & 19 \\
\hline Taiwan & 43 & 30 & 21 \\
\hline Dominican Republic & 50 & 29 & 17 \\
\hline Malaysia & 32 & 23 & 16 \\
\hline Singapore & 29 & 22 & 15 \\
\hline Costa Rica & 36 & 21 & 12 \\
\hline Turkey & 22 & 18 & 15 \\
\hline Colombia & 26 & 18 & 11 \\
\hline Mauritius & 18 & 14 & 11 \\
\hline Brazil & 16 & 12 & 8 \\
\hline Romania & 16 & 11 & 8 \\
\hline Mexico & 16 & 9 & 7 \\
\hline Egypt & 12 & 9 & 6 \\
\hline Poland & 14 & 8 & 5 \\
\hline Japan & 10 & 7 & 3 \\
\hline Jamaica & 5 & 2 & 1 \\
\hline Honduras & 0 & 0 & 0 \\
\hline
\end{tabular}

Notes: Table reports the fraction of specific limits with fill rates that exceed 80, 90 and 95 percent, respectively. Authors' calculations from U.S. MFA/ATC Database.

Table 6: Top 30 Countries in Terms of Binding Quotas, 1984 to 2004 


\begin{tabular}{lc} 
Country & $\begin{array}{c}\text { Fraction of } \\
\text { Specific } \\
\text { Limits (\%) }\end{array}$ \\
\hline China & 61 \\
Korea, South & 53 \\
Taiwan & 51 \\
Hong Kong & 46 \\
Indonesia & 42 \\
Thailand & 41 \\
Malaysia & 39 \\
Mexico & 38 \\
Sri Lanka & 38 \\
Romania & 33 \\
Philippines & 31 \\
Japan & 31 \\
Pakistan & 25 \\
Turkey & 25 \\
India & 22 \\
Macau & 22 \\
Brazil & 22 \\
Poland & 22 \\
Singapore & 21 \\
Uae & 20 \\
Bangladesh & 20 \\
Mauritius & 18 \\
Cambodia & 17 \\
Dominican Republic & 16 \\
Jamaica & 15 \\
Egypt & 9 \\
Colombia & 6 \\
Guatemala & 4 \\
Costa Rica & 4 \\
Honduras & 4 \\
\hline \hline Notes: The Table reports the \\
fraction of OTEXA categories \\
exported by the country that were \\
subject to specific limits from $1990-$ \\
2004. The table lists the thirty \\
countries with the largest aggregate \\
base quotas. Source: Authors' \\
calculations from U.S. MFA/ATC \\
Database. & \\
&
\end{tabular}

Table 7: Fraction of Specific Limits, Top 30 Countries 


\begin{tabular}{|c|c|c|c|c|c|c|}
\hline MFA Group & Description & Fill Rate (\%) & $\begin{array}{c}\text { China's } \\
\text { Fill Rate } \\
(\%)\end{array}$ & $\begin{array}{l}\text { Bangladesh's } \\
\text { Fill Rate (\%) }\end{array}$ & $\begin{array}{c}\text { India's Fill } \\
\text { Rate (\%) }\end{array}$ & $\begin{array}{l}\text { Base } \\
\text { Quota } \\
\text { (SME) }\end{array}$ \\
\hline $300 / 301$ & Cotton Yarns & 54 & 52 & - & 12 & 7.2 \\
\hline 313 & Cotton Sheeting Fabric & 50 & 93 & - & 70 & 8.6 \\
\hline 314 & Cotton Poplin / Broadcloth Fab. & 51 & 95 & - & 54 & 4.8 \\
\hline 315 & Cotton Printcloth Fabric & 67 & 97 & - & 75 & 8.0 \\
\hline *340/640 & Non-Knit Shirts & 69 & 99 & 64 & 99 & 12.8 \\
\hline $347 / 348$ & Cotton Trousers & 83 & 99 & 99 & 98 & 10.3 \\
\hline *352/652 & Underwear & 77 & 85 & 97 & - & 8.6 \\
\hline $638 / 639$ & Mmf Knit Shirts & 83 & 98 & 96 & - & 9.5 \\
\hline $645 / 646$ & Mmf Sweaters & 55 & 95 & 92 & - & 7.9 \\
\hline *647/648 & Mmf Trousers & 80 & 99 & 100 & 93 & 8.5 \\
\hline
\end{tabular}

Table 8: Fill Rates by OTEXA Category, Top 10 Categories 


\begin{tabular}{lcc} 
& Log $(\mathrm{ETE})$ & $\log (\mathrm{ETE})$ \\
\hline Fill Rate & $2.1^{\star * \star}$ & $1.4^{\star * *}$ \\
& $0.2^{*}$ & $0.2^{\circ}$ \\
\hline Year FE & Yes & Yes \\
Category FE & No & Yes \\
R-squared & 0.21 & 0.80 \\
Observations & 417 & 417 \\
\hline \hline
\end{tabular}

Notes: The dependent variable is the log export tax equivalent (see text). Column 2 includes OTEXA category fixed effects. Significance: * 10 percent, ** 5 percent, ${ }^{* * *} 1$ percent. Source: Chinese export license prices obtained from www.chinaquota.com.

Table 9: Export Tax Equivalents and Fill Rates 


\begin{tabular}{|c|c|c|}
\hline Country & $\begin{array}{l}\text { Fraction of Groups } \\
\text { with Adjustments }\end{array}$ & $\begin{array}{c}\text { Flexibility Adjustment } \\
\text { Margin }\end{array}$ \\
\hline Cambodia & 99 & 15 \\
\hline Guatemala & 97 & 7 \\
\hline Bangladesh & 97 & 11 \\
\hline Dominican Republic & 95 & 8 \\
\hline India & 93 & 8 \\
\hline Philippines & 92 & 11 \\
\hline China & 92 & 5 \\
\hline Indonesia & 89 & 10 \\
\hline Pakistan & 88 & 8 \\
\hline Sri Lanka & 88 & 11 \\
\hline UAE & 84 & 6 \\
\hline Macau & 81 & 6 \\
\hline Thailand & 80 & 6 \\
\hline Honduras & 78 & 4 \\
\hline Hong Kong & 75 & 5 \\
\hline Taiwan & 71 & 5 \\
\hline Korea, South & 65 & 4 \\
\hline Turkey & 60 & 2 \\
\hline Costa Rica & 60 & 1 \\
\hline Singapore & 52 & 0 \\
\hline Malaysia & 50 & 0 \\
\hline Colombia & 45 & 0 \\
\hline Romania & 30 & 0 \\
\hline Brazil & 27 & 0 \\
\hline Mauritius & 25 & 0 \\
\hline Mexico & 25 & 0 \\
\hline Egypt & 16 & 0 \\
\hline Poland & 15 & 0 \\
\hline Japan & 7 & 0 \\
\hline Jamaica & 6 & 0 \\
\hline \multicolumn{3}{|c|}{$\begin{array}{l}\text { Notes: Column } 1 \text { reports the median flexibility adjustment margin } \\
\text { between } 1984-2004 \text {. Column } 2 \text { displays the fraction of MFA groups } \\
\text { that were subject to at least one flexibility adjustment. The table } \\
\text { lists the thirty countries with the largest aggregate base quotas. } \\
\text { Source: Authors' calculations from U.S. MFA/ATC Database. }\end{array}$} \\
\hline
\end{tabular}

Table 10: Flexibility Use, 1984-2004 


\begin{tabular}{|c|c|c|c|c|c|c|c|c|c|c|c|c|}
\hline \multirow[b]{2}{*}{ Region } & \multicolumn{3}{|c|}{ Phase I } & \multicolumn{3}{|c|}{ Phase II } & \multicolumn{3}{|c|}{ Phase III } & \multicolumn{3}{|c|}{ Phase IV } \\
\hline & $\begin{array}{c}\text { Aggregate } \\
\text { Growth }\end{array}$ & $\begin{array}{l}\text { Intensive } \\
\text { Margin }\end{array}$ & $\begin{array}{c}\text { Extensive } \\
\text { Margin }\end{array}$ & $\begin{array}{c}\text { Aggregate } \\
\text { Growth }\end{array}$ & $\begin{array}{l}\text { Intensive } \\
\text { Margin }\end{array}$ & $\begin{array}{c}\text { Extensive } \\
\text { Margin }\end{array}$ & $\begin{array}{c}\text { Aggregate } \\
\text { Growth }\end{array}$ & $\begin{array}{c}\text { Intensive } \\
\text { Margin }\end{array}$ & $\begin{array}{c}\text { Extensive } \\
\text { Margin }\end{array}$ & $\begin{array}{c}\text { Aggregate } \\
\text { Growth }\end{array}$ & $\begin{array}{l}\text { Intensive } \\
\text { Margin }\end{array}$ & $\begin{array}{c}\text { Extensive } \\
\text { Margin }\end{array}$ \\
\hline China & 9 & 16 & -6 & 9 & 10 & -1 & 306 & 288 & 17 & 271 & 269 & 2 \\
\hline Caribbean & 47 & 23 & 24 & 0 & 0 & -1 & -12 & -12 & 0 & -1 & 1 & -2 \\
\hline Central America & 33 & 6 & 27 & -10 & -3 & -7 & 6 & 10 & -4 & 1 & 3 & -2 \\
\hline East Asia & -10 & -10 & 0 & 24 & 24 & 0 & 57 & 22 & 36 & -24 & -25 & 0 \\
\hline European Union & 2 & 3 & -1 & -3 & -3 & 0 & 13 & 12 & 2 & 64 & 64 & 0 \\
\hline Former Soviet Union & -50 & -45 & -5 & -21 & -22 & 1 & -18 & -18 & 0 & -61 & -51 & -10 \\
\hline Middle East & -34 & -43 & 9 & -1 & -2 & 2 & 15 & 13 & 2 & -12 & -12 & 0 \\
\hline North Africa & -46 & -31 & -15 & 23 & 23 & 0 & -8 & -27 & 19 & -4 & -4 & 0 \\
\hline North America & 13 & 10 & 3 & 5 & 5 & 0 & 4 & 5 & -1 & -14 & -13 & -1 \\
\hline Oceania & -42 & 12 & -54 & 48 & 45 & 3 & -15 & -15 & 1 & -52 & -49 & -3 \\
\hline Other Europe & 102 & -36 & 138 & 12 & -6 & 18 & 21 & -9 & 30 & -30 & -30 & -1 \\
\hline South America & -65 & -58 & -7 & -51 & -51 & 0 & 44 & 44 & -1 & -13 & -12 & -1 \\
\hline South Asia & 33 & 33 & 0 & 18 & 18 & 0 & 5 & 3 & 2 & 20 & 19 & 0 \\
\hline Southeast Asia & -47 & 8 & -54 & 18 & 18 & 0 & -13 & -13 & 0 & 0 & 0 & 0 \\
\hline Sub-Saharan Africa & -53 & -42 & -11 & 10 & -25 & 34 & 69 & 60 & 9 & -16 & -15 & -1 \\
\hline All Regions & 3 & 2 & 1 & 3 & 3 & 0 & 31 & 27 & 4 & 14 & 14 & 0 \\
\hline All Regions (ex. China) & 3 & 1 & 2 & 2 & 2 & 0 & 9 & 6 & 4 & -2 & -1 & 0 \\
\hline China (2002) & 42 & 41 & 1 & 32 & 21 & 11 & & & & & & \\
\hline All Regions (2002) & 8 & 19 & -12 & 14 & 11 & 3 & & & & & & \\
\hline \multicolumn{13}{|c|}{$\begin{array}{l}\text { Notes: Decomposition table reports aggregate growth, decomposed into the extensive and intensive margins, by phase and region, in year of integration. In } \\
\text { this table, the integration years for Phase I-IV are for 1995, 1998, } 2002 \text { and 2005, respectively. Extensive margin is defined as the net SME quantity growth in } \\
\text { varieties that enter and exit in the year of integration. Intensive margin is defined as the net SME quantity growth in continuing varieties in the year of } \\
\text { integration. Note that the aggregate growth values for Phase I and II differ from the previous table because this table reports values for } 1995 \text { and } 1998 \text {, } \\
\text { respectively. The bottom rows in each panel report Phase I and II export growth for China and all regions in 2002, the year that China was eligible for ATC } \\
\text { liberalization. The sum of the intensive and extensive margin may not sum to aggregate growth due to rounding. }\end{array}$} \\
\hline
\end{tabular}

Table 11: Aggregate Growth Decomposition, by Phase and Region 


\begin{tabular}{|c|c|c|c|c|c|c|c|c|}
\hline \multirow[b]{2}{*}{ Coefficients } & \multicolumn{2}{|c|}{$\begin{array}{c}\text { Phase I } \\
\Delta \operatorname{Ln}(\text { SME) }\end{array}$} & \multicolumn{2}{|c|}{$\begin{array}{c}\text { Phase II } \\
\Delta \operatorname{Ln}(\mathrm{SME})\end{array}$} & \multicolumn{2}{|c|}{$\begin{array}{c}\text { Phase III } \\
\Delta \operatorname{Ln}(\mathrm{SME})\end{array}$} & \multicolumn{2}{|c|}{$\begin{array}{c}\text { Phase IV } \\
\Delta \operatorname{Ln}(\mathrm{SME})\end{array}$} \\
\hline & Unbound & Bound & Unbound & Bound & Unbound & Bound & Unbound & Bound \\
\hline Integration Year (2002 fo & hase I-III) & & & & & & & \\
\hline $\mathrm{x}$ China & $\begin{array}{l}0.41 \\
0.11\end{array}$ & $\begin{array}{l}0.00 \\
0.00\end{array}$ & $\begin{array}{l}0.93^{\star \star \star \star} \\
0.11\end{array}$ & $\begin{array}{l}2.26^{\star \star \star} \\
0.24\end{array}$ & $\begin{array}{l}1.36^{\star \star \star} \\
0.14\end{array}$ & $\begin{array}{l}1.81^{\star \star \star *} \\
0.18\end{array}$ & $\begin{array}{l}1.28^{\star * *} \\
0.07\end{array}$ & $\begin{array}{l}1.73^{* * \star} \\
0.08\end{array}$ \\
\hline $\mathrm{x}$ Caribbean & $\begin{array}{l}0.21 \\
0.33\end{array}$ & $\begin{array}{l}0.00 \\
0.00\end{array}$ & $\begin{array}{r}-0.16 \\
0.27\end{array}$ & $\begin{array}{r}-0.17 \\
0.17\end{array}$ & $\begin{array}{r}-0.38 \\
0.58\end{array}$ & $\begin{array}{l}-0.25 \text { * } \\
0.14\end{array}$ & $\begin{array}{l}-0.36 \text { *** } \\
0.05\end{array}$ & $\begin{array}{l}-0.30^{\text {*** }} \\
0.06\end{array}$ \\
\hline$x$ Central America & $\begin{array}{c}-0.26 \text { * } \\
0.15\end{array}$ & $\begin{array}{l}0.00 \\
0.00\end{array}$ & $\begin{array}{r}-0.13 \\
0.11\end{array}$ & $\begin{array}{r}-0.05 \\
0.07\end{array}$ & $\begin{array}{l}0.30^{*} \\
0.17\end{array}$ & $\begin{array}{l}0.10 \\
0.10\end{array}$ & $\begin{array}{r}-0.19 \\
0.11\end{array}$ & 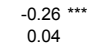 \\
\hline x East Asia & $\begin{array}{l}0.16 \\
0.13\end{array}$ & $\begin{array}{l}0.00 \\
0.00\end{array}$ & $\begin{array}{l}0.17^{\text {** }} \\
0.07\end{array}$ & $\begin{array}{l}-0.68^{\star \star *} \\
0.19\end{array}$ & $\begin{array}{l}0.09 \\
0.10\end{array}$ & $\begin{array}{l}0.00 \\
0.16\end{array}$ & $\begin{array}{l}-0.22 \text { *** } \\
0.08\end{array}$ & $\begin{array}{l}-0.58^{\text {*** }} \\
0.10\end{array}$ \\
\hline x European Union & $\begin{array}{l}0.01 \\
0.05\end{array}$ & $\begin{array}{l}0.00 \\
0.00\end{array}$ & $\begin{array}{r}-0.02 \\
0.04\end{array}$ & $\begin{array}{r}-0.12 \\
0.16\end{array}$ & $\begin{array}{r}-0.01 \\
0.04\end{array}$ & $\begin{array}{l}0.05 \\
0.08\end{array}$ & $\begin{array}{l}-0.15 \text { *** } \\
0.02\end{array}$ & $\begin{array}{l}-0.20 * \star \star \\
0.04\end{array}$ \\
\hline x Former Soviet Union & $\begin{array}{l}0.09 \\
0.43\end{array}$ & $\begin{array}{l}0.00 \\
0.00\end{array}$ & $\begin{array}{l}0.28 \\
0.24\end{array}$ & $\begin{array}{r}-0.07 \\
0.22\end{array}$ & $\begin{array}{l}-0.49^{* * *} \\
0.11\end{array}$ & $\begin{array}{r}-0.22 \\
0.45\end{array}$ & $\begin{array}{l}-0.92 \text { *** } \\
0.30\end{array}$ & $\begin{array}{l}-1.144^{\text {** }} \\
0.56\end{array}$ \\
\hline $\mathrm{x}$ Middle East & $\begin{array}{r}-0.07 \\
0.25\end{array}$ & $\begin{array}{l}0.00 \\
0.00\end{array}$ & $\begin{array}{l}0.08 \\
0.15\end{array}$ & $\begin{array}{l}0.11 \\
0.24\end{array}$ & $\begin{array}{l}0.11 \\
0.20\end{array}$ & $\begin{array}{r}-0.22 \\
0.14\end{array}$ & $\begin{array}{l}-0.32 \text { *** } \\
0.09\end{array}$ & 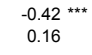 \\
\hline$x$ North Africa & $\begin{array}{l}0.35 \\
0.28\end{array}$ & $\begin{array}{l}0.00 \\
0.00\end{array}$ & 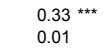 & $\begin{array}{l}0.31 \\
0.26\end{array}$ & $\begin{array}{l}-0.17^{* * *} \\
0.04\end{array}$ & $\begin{array}{r}-0.25 \\
0.50\end{array}$ & $\begin{array}{l}0.01 \\
0.03\end{array}$ & $\begin{array}{r}-0.09 \\
0.08\end{array}$ \\
\hline x North America & $\begin{array}{l}0.01 \\
0.04\end{array}$ & $\begin{array}{l}0.00 \\
0.00\end{array}$ & $\begin{array}{l}0.05 \\
0.07\end{array}$ & $\begin{array}{r}-0.19 \\
0.16\end{array}$ & $\begin{array}{l}-0.11^{\star \star \star} \\
0.02\end{array}$ & $\begin{array}{l}-0.07^{* \star *} \\
0.00\end{array}$ & $\begin{array}{l}-0.29 \text { ** } \\
0.12\end{array}$ & $\begin{array}{l}-0.20 \text { ** } \\
0.09\end{array}$ \\
\hline x Oceania & $\begin{array}{l}-0.26 \text { ** } \\
0.10\end{array}$ & $\begin{array}{l}0.00 \\
0.00\end{array}$ & $\begin{array}{l}-0.17^{\text {***}} \\
0.06\end{array}$ & $\begin{array}{l}-0.55^{\star \star \star} \\
0.06\end{array}$ & $\begin{array}{r}-0.13 \\
0.25\end{array}$ & $\begin{array}{l}0.03 \\
0.29\end{array}$ & $\begin{array}{l}-0.19^{\star \star \star} \\
0.05\end{array}$ & $\begin{array}{l}-0.26^{\text {***}} \\
0.09\end{array}$ \\
\hline$x$ Other Europe & $\begin{array}{l}0.06 \\
0.06\end{array}$ & $\begin{array}{l}0.00 \\
0.00\end{array}$ & $\begin{array}{l}-0.12 \text { *** } \\
0.03\end{array}$ & $\begin{array}{l}1.72 \text { ** } \\
0.71\end{array}$ & $\begin{array}{r}-0.11 \\
0.10\end{array}$ & $\begin{array}{l}0.14 \\
0.12\end{array}$ & $\begin{array}{r}-0.02 \\
0.10\end{array}$ & $\begin{array}{r}-0.04 \\
0.15\end{array}$ \\
\hline x South America & $\begin{array}{r}-0.15 \\
0.15\end{array}$ & $\begin{array}{l}0.00 \\
0.00\end{array}$ & $\begin{array}{l}0.03 \\
0.17\end{array}$ & $\begin{array}{l}0.33 \text { * } \\
0.18\end{array}$ & $\begin{array}{l}0.21 \\
0.14\end{array}$ & $\begin{array}{l}0.29 \\
0.25\end{array}$ & $\begin{array}{r}-0.14 \\
0.10\end{array}$ & $\begin{array}{r}-0.11 \\
0.08\end{array}$ \\
\hline x South Asia & $\begin{array}{l}0.31^{* \star *} \\
0.10\end{array}$ & $\begin{array}{l}0.00 \\
0.00\end{array}$ & 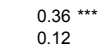 & $\begin{array}{r}-0.07 \\
0.21\end{array}$ & $\begin{array}{l}0.22 \text { * } \\
0.12\end{array}$ & $\begin{array}{l}0.34 \\
0.37\end{array}$ & $\begin{array}{l}0.09 \\
0.11\end{array}$ & $\begin{array}{r}-0.08 \\
0.09\end{array}$ \\
\hline x Southeast Asia & $\begin{array}{l}0.34 \\
0.26\end{array}$ & $\begin{array}{l}0.00 \\
0.00\end{array}$ & $\begin{array}{l}0.23 \\
0.14\end{array}$ & $\begin{array}{l}0.20 \\
0.28\end{array}$ & $\begin{array}{l}0.26 \\
0.22\end{array}$ & $\begin{array}{l}0.06 \\
0.28\end{array}$ & $\begin{array}{r}-0.04 \\
0.07\end{array}$ & $\begin{array}{r}-0.11 \\
0.09\end{array}$ \\
\hline x Sub-Saharan Africa & $\begin{array}{r}-0.10 \\
0.14\end{array}$ & $\begin{array}{l}0.00 \\
0.00\end{array}$ & $\begin{array}{l}0.02 \\
0.18\end{array}$ & $\begin{array}{l}0.16 \text { *夫 } \\
0.08\end{array}$ & $\begin{array}{l}0.38 \text { * } \\
0.20\end{array}$ & $\begin{array}{r}-0.26 \\
0.40\end{array}$ & $\begin{array}{l}-0.31 \text { ** } \\
0.14\end{array}$ & $\begin{array}{l}-0.50^{\star \star \star} \\
0.12\end{array}$ \\
\hline Observations & 41,100 & & 88,818 & & 97,482 & & 431,069 & \\
\hline
\end{tabular}

Table 12: ATC Phase-outs: Export Quantities and Binding Quotas 


\begin{tabular}{|c|c|c|c|}
\hline Kuwait (-2.89) & Taiwan $(-0.55)$ & UAE $(-0.26)$ & Mozambique (0.05) \\
\hline Russia (-2.81) & Swaziland $(-0.54)$ & Ukraine $(-0.25)$ & Malawi $(0.05)$ \\
\hline Maldives (-2.35) & Sweden $(-0.52)$ & El Salvador $(-0.23)$ & Slovakia $(0.06)$ \\
\hline Micronesia $(-2.14)$ & Ghana $(-0.51)$ & Guatemala $(-0.23)$ & Trinidad and Tobago (0.09) \\
\hline Georgia (-1.99) & Mali $(-0.48)$ & Gambia $(-0.23)$ & Iceland $(0.09)$ \\
\hline Guinea (-1.85) & Bahrain $(-0.48)$ & Turkey $(-0.23)$ & Vietnam (0.09) \\
\hline Oman $(-1.82)$ & Mauritius $(-0.47)$ & Czech Republic $(-0.21)$ & Chile $(0.11)$ \\
\hline Suriname $(-1.38)$ & Slovenia $(-0.46)$ & Lebanon $(-0.21)$ & Germany $(0.12)$ \\
\hline Cyprus (-1.35) & Poland $(-0.45)$ & Nicaragua $(-0.21)$ & Cambodia (0.12) \\
\hline Albania (-1.25) & Venezuela $(-0.45)$ & Colombia $(-0.20)$ & Indonesia $(0.13)$ \\
\hline Kyrgyzstan (-1.24) & Argentina $(-0.45)$ & Ecuador $(-0.18)$ & Bangladesh $(0.15)$ \\
\hline Kazakhstan $(-1.21)$ & Hungary $(-0.44)$ & Brunei $(-0.17)$ & Switzerland (0.16) \\
\hline Azerbaijan (-1.13) & Barbados $(-0.40)$ & Australia $(-0.15)$ & Armenia (0.16) \\
\hline Tajikistan (-1.09) & Belarus $(-0.39)$ & Brazil $(-0.15)$ & Uzbekistan (0.18) \\
\hline Macedonia (Skopje) $(-1.00)$ & Malaysia $(-0.39)$ & Belgium $(-0.15)$ & Cook Islands (0.18) \\
\hline South Africa $(-0.98)$ & Honduras $(-0.37)$ & Ireland $(-0.14)$ & Bolivia $(0.22)$ \\
\hline Ivory Coast (-0.91) & Costa Rica $(-0.36)$ & United Kingdom $(-0.14)$ & Jordan $(0.24)$ \\
\hline Ethiopia $(-0.91)$ & Romania $(-0.35)$ & Italy $(-0.13)$ & Peru $(0.24)$ \\
\hline Syria $(-0.90)$ & Finland $(-0.35)$ & Spain $(-0.13)$ & Panama (0.25) \\
\hline Moldova $(-0.87)$ & Greece $(-0.35)$ & Japan $(-0.12)$ & Botswana $(0.26)$ \\
\hline Korea, South $(-0.85)$ & Guyana $(-0.34)$ & Namibia $(-0.11)$ & Uganda $(0.30)$ \\
\hline Mongolia $(-0.84)$ & Dominican Republic $(-0.34)$ & Uruguay $(-0.10)$ & Saudi Arabia (0.32) \\
\hline Nepal $(-0.77)$ & Haiti $(-0.34)$ & Portugal $(-0.10)$ & Nigeria (0.48) \\
\hline Israel $(-0.72)$ & Fiji $(-0.33)$ & Croatia $(-0.10)$ & Qatar (0.51) \\
\hline Singapore $(-0.69)$ & Latvia $(-0.32)$ & Estonia $(-0.07)$ & Bosnia-Hercegovina (0.63) \\
\hline Zambia $(-0.69)$ & Sri Lanka $(-0.31)$ & Mexico $(-0.07)$ & Senegal $(0.67)$ \\
\hline Bermuda $(-0.69)$ & Canada $(-0.31)$ & Paraguay $(-0.04)$ & British Virgin Islands (0.69) \\
\hline Sierra Leone $(-0.68)$ & Austria $(-0.31)$ & Turkmenistan $(-0.04)$ & San Marino (0.75) \\
\hline Jamaica $(-0.65)$ & New Zealand $(-0.31)$ & Kenya $(-0.02)$ & Malta $(0.90)$ \\
\hline Cape Verde $(-0.62)$ & Zimbabwe $(-0.30)$ & Morocco $(-0.02)$ & Bahamas (1.35) \\
\hline Hong Kong $(-0.62)$ & France $(-0.30)$ & Tanzania $(0.01)$ & Netherlands Antilles (1.60) \\
\hline Belize $(-0.61)$ & Egypt $(-0.29)$ & Lithuania (0.02) & Laos (1.88) \\
\hline Denmark (-0.59) & Norway $(-0.28)$ & Tunisia (0.02) & Somalia (1.94) \\
\hline Madagascar $(-0.57)$ & Philippines $(-0.28)$ & Pakistan (0.02) & Tokelau (2.05) \\
\hline Lesotho $(-0.57)$ & Bulgaria $(-0.27)$ & India (0.03) & Mauritania (3.43) \\
\hline Macao $(-0.55)$ & Thailand $(-0.26)$ & Netherlands $(0.05)$ & \\
\hline
\end{tabular}

Table 13: "Winners and Losers" 


\begin{tabular}{|c|c|c|c|c|c|c|c|c|}
\hline \multirow[b]{2}{*}{ Coefficients } & \multicolumn{2}{|c|}{$\begin{array}{c}\text { Phase I } \\
\Delta \text { Ln (Price) }\end{array}$} & \multicolumn{2}{|c|}{$\begin{array}{c}\text { Phase II } \\
\Delta \operatorname{Ln} \text { (Price) }\end{array}$} & \multicolumn{2}{|c|}{$\begin{array}{c}\text { Phase III } \\
\Delta \operatorname{Ln} \text { (Price) }\end{array}$} & \multicolumn{2}{|c|}{$\begin{array}{c}\text { Phase IV } \\
\Delta \operatorname{Ln} \text { (Price) }\end{array}$} \\
\hline & Unbound & Bound & Unbound & Bound & Unbound & Bound & Unbound & Bound \\
\hline \multicolumn{9}{|l|}{ Integration Year } \\
\hline x China & $\begin{array}{r}-0.17 \\
0.10\end{array}$ & & $\begin{array}{r}-0.07 \\
0.05\end{array}$ & $\begin{array}{l}0.11 \\
0.14\end{array}$ & 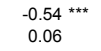 & $\begin{array}{l}-0.666^{\star \star \star} \\
0.09\end{array}$ & $\begin{array}{l}-0.37^{\star \star \star \star} \\
0.02^{*}\end{array}$ & $\begin{array}{l}-0.53^{\star \star \star} \\
0.03\end{array}$ \\
\hline x Caribbean & $\begin{array}{r}-0.08 \\
0.24\end{array}$ & & $\begin{array}{r}-0.10 \\
0.08\end{array}$ & & $\begin{array}{l}-0.17^{*} \\
0.10^{*}\end{array}$ & & $\begin{array}{r}-0.02 \\
0.03\end{array}$ & \\
\hline $\mathrm{x}$ Central America & $\begin{array}{r}-0.13 \\
0.18\end{array}$ & & $\begin{array}{r}-0.01 \\
0.06\end{array}$ & & $\begin{array}{r}-0.03 \\
0.06\end{array}$ & & $\begin{array}{r}-0.03 \\
0.02\end{array}$ & $\begin{array}{r}-0.03 \\
0.49\end{array}$ \\
\hline $\mathrm{x}$ East Asia & $\begin{array}{l}0.07 \\
0.06\end{array}$ & & $\begin{array}{l}-0.08^{\text {** }} \\
0.03\end{array}$ & & $\begin{array}{l}-0.17^{\star \star \star} \\
0.03^{*}\end{array}$ & $\begin{array}{r}-0.14 \\
0.14\end{array}$ & $\begin{array}{r}-0.01 \\
0.01\end{array}$ & $\begin{array}{l}-0.15 \text { ** } \\
0.06\end{array}$ \\
\hline x European Union & $\begin{array}{l}0.00 \\
0.04\end{array}$ & & $\begin{array}{r}-0.01 \\
0.02\end{array}$ & & $\begin{array}{r}-0.01 \\
0.02\end{array}$ & & $\begin{array}{l}0.01 \text { * } \\
0.01\end{array}$ & $\begin{array}{l}0.05 \\
0.13\end{array}$ \\
\hline x Former Soviet Union & $\begin{array}{l}0.03 \\
0.47\end{array}$ & & $\begin{array}{r}-0.11 \\
0.12\end{array}$ & & $\begin{array}{l}0.13 \\
0.09\end{array}$ & $\begin{array}{r}-0.09 \\
0.39\end{array}$ & $\begin{array}{l}0.16^{\text {***}} \\
0.03\end{array}$ & $\begin{array}{l}0.03 \\
0.18\end{array}$ \\
\hline x Middle East & $\begin{array}{l}0.00 \\
0.21\end{array}$ & & $\begin{array}{l}0.05 \\
0.06\end{array}$ & & $\begin{array}{r}-0.04 \\
0.05\end{array}$ & $\begin{array}{r}-0.15 \\
0.33\end{array}$ & $\begin{array}{l}0.02 \\
0.02\end{array}$ & $\begin{array}{l}0.02 \\
0.16\end{array}$ \\
\hline$x$ North Africa & $\begin{array}{l}0.31 \\
0.30\end{array}$ & & $\begin{array}{l}0.06 \\
0.09\end{array}$ & & $\begin{array}{l}0.10 \\
0.08\end{array}$ & & $\begin{array}{l}0.03 \\
0.03\end{array}$ & \\
\hline$x$ North America & $\begin{array}{l}0.01 \\
0.08\end{array}$ & & $\begin{array}{l}0.05 \\
0.04\end{array}$ & & $\begin{array}{l}0.00 \\
0.04\end{array}$ & & $\begin{array}{l}0.03 \\
0.02\end{array}$ & \\
\hline x Oceania & $\begin{array}{l}0.10 \\
0.18\end{array}$ & & $\begin{array}{r}-0.08 \\
0.08\end{array}$ & & $\begin{array}{l}0.01 \\
0.08\end{array}$ & & $\begin{array}{l}0.03 \\
0.03\end{array}$ & \\
\hline x Other Europe & $\begin{array}{l}0.04 \\
0.12\end{array}$ & & $\begin{array}{r}-0.01 \\
0.07\end{array}$ & & $\begin{array}{l}-0.13^{\text {** }} \\
0.06\end{array}$ & & $\begin{array}{l}0.01 \\
0.02\end{array}$ & $\begin{array}{l}0.16 \\
0.70\end{array}$ \\
\hline$x$ South America & $\begin{array}{l}0.39 \text { ** } \\
0.15\end{array}$ & & $\begin{array}{r}-0.07 \\
0.06\end{array}$ & & $\begin{array}{r}-0.06 \\
0.05\end{array}$ & & $\begin{array}{l}0.04 \text { ** } \\
0.02\end{array}$ & $\begin{array}{r}-0.17 \\
0.35\end{array}$ \\
\hline x South Asia & $\begin{array}{l}0.12 \\
0.09\end{array}$ & & $\begin{array}{r}-0.02 \\
0.04\end{array}$ & $\begin{array}{r}-0.10 \\
0.86\end{array}$ & $\begin{array}{l}-0.15^{\star \star \star *} \\
0.04\end{array}$ & $\begin{array}{c}-0.49 \text { * } \\
0.27\end{array}$ & $\begin{array}{l}-0.07^{* \star *} \\
0.01\end{array}$ & $\begin{array}{l}-0.20^{\text {** }} \\
0.08\end{array}$ \\
\hline x Southeast Asia & $\begin{array}{l}0.26 \text { ** } \\
0.10\end{array}$ & & $\begin{array}{l}-0.13^{* \star *} \\
0.04\end{array}$ & & $\begin{array}{l}-0.13^{\star \star \star *} \\
0.03\end{array}$ & $\begin{array}{l}0.12 \\
0.39\end{array}$ & $\begin{array}{l}-0.04 \text { *** } \\
0.01\end{array}$ & $\begin{array}{l}-0.14 \text { * } \\
0.07\end{array}$ \\
\hline x Sub-Saharan Africa & $\begin{array}{l}0.18 \\
0.21\end{array}$ & & $\begin{array}{r}-0.16 \\
0.10 \\
\end{array}$ & & $\begin{array}{l}-0.19^{\text {** }} \\
0.08\end{array}$ & & 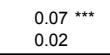 & \\
\hline Year $2002 \times$ China & $\begin{array}{c}-0.14 \text { * } \\
0.08\end{array}$ & & $\begin{array}{l}{ }^{-0.38} \\
0.05\end{array}$ & $\begin{array}{l}-0.81^{\star \star \star} \\
0.13^{*}\end{array}$ & & & & \\
\hline Observations & 41,100 & & 88,818 & & 97,482 & & 431,069 & \\
\hline
\end{tabular}

Table 14: ATC Phase-outs: Unit Values and Binding Quotas 


\begin{tabular}{|c|c|c|c|c|c|c|c|c|}
\hline & \multicolumn{2}{|c|}{ Phase I } & \multicolumn{2}{|c|}{ Phase II } & \multicolumn{2}{|c|}{ Phase III } & \multicolumn{2}{|c|}{ Phase IV } \\
\hline & Unbound & Bound & Unbound & Bound & Unbound & Bound & Unbound & Bound \\
\hline China & $\begin{array}{l}0.10 \\
0.05\end{array}$ & & $\begin{array}{l}0.49^{\text {*** }} \\
0.08\end{array}$ & $\begin{array}{l}0.81^{\text {*** }} \\
0.19\end{array}$ & $\begin{array}{l}0.99^{* * *} \\
0.14\end{array}$ & $\begin{array}{l}1.03^{\text {*** }} \\
0.21\end{array}$ & $\begin{array}{l}1.01^{* * *} \\
0.06\end{array}$ & $\begin{array}{l}0.72^{\text {*** }} \\
0.08\end{array}$ \\
\hline ROW & $\begin{array}{r}-0.01 \\
0.01\end{array}$ & & $\begin{array}{l}0.03 \\
0.02\end{array}$ & $\begin{array}{l}-0.12^{* * *} \\
0.03\end{array}$ & $\begin{array}{l}0.07^{* *} \\
0.03\end{array}$ & $\begin{array}{l}0.40^{* * *} \\
0.05^{*}\end{array}$ & $\begin{array}{l}-0.03 \text { * } \\
0.01\end{array}$ & $\begin{array}{l}0.15^{* * *} \\
0.02\end{array}$ \\
\hline Diff-in-Diff & $\begin{array}{l}0.11 \\
0.05\end{array}$ & & $\begin{array}{l}0.47^{* *} \\
0.21\end{array}$ & & $\begin{array}{r}-0.29 \\
0.26\end{array}$ & & 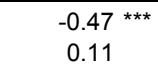 & \\
\hline Observations & 40,186 & & 88,415 & & 97,106 & & 429,488 & \\
\hline
\end{tabular}

Notes: Table regresses change in the country-product quality on year-region-unbound versus bound interactions. The procedure to estimate quality is discussed in the Appendix. Bound refer to the HS codes in which China had greater than a 90 percent fill rate in the previous year. Phase I-III coefficients are for 2002, the year China entered the WTO, and Phase IV reports 2005 coefficients. The difference-in-differences are computed as the change in China's bound and unbound coefficients minus the analogus difference in ROW coefficients. Significance: ${ }^{*} 10$ percent, ${ }^{* *} 5$ percent, ${ }^{* * *} 1$ percent.

Table 15: ATC Phase-outs: Export Qualities and Binding Quotas 
2007 Quota

\begin{tabular}{lcccc} 
MFA Groups & Unit & 2006 Quota & 2007 Quota & Growth \\
\hline Cotton fabrics & $\mathrm{kg}$ & $61,948,000$ & $69,692,000$ & 12.5 \\
T-shirts & no & $540,204,000$ & $594,000,000$ & 10.0 \\
Children's sub-limit & no & $45,017,000$ & $49,518,000$ & 10.0 \\
Pullovers & no & $189,719,000$ & $220,000,000$ & 16.0 \\
Men's trousers & no & $338,923,000$ & $383,000,000$ & 13.0 \\
Blouses & no & $80,493,000$ & $88,543,000$ & 10.0 \\
Bed linen & kg & $15,795,000$ & $17,770,000$ & 12.5 \\
Dresses & no & $27,001,000$ & $29,701,000$ & 10.0 \\
Brassieres & no & $219,882,000$ & $248,000,000$ & 12.8 \\
Table \& kitchen linen & kg & $12,349,000$ & $13,892,000$ & 12.5 \\
Flax or ramie yarn & kg & $4,740,000$ & $5,214,000$ & 10.0 \\
\hline
\end{tabular}

Table 16: EU Safeguards on China's TC, 2006-07 


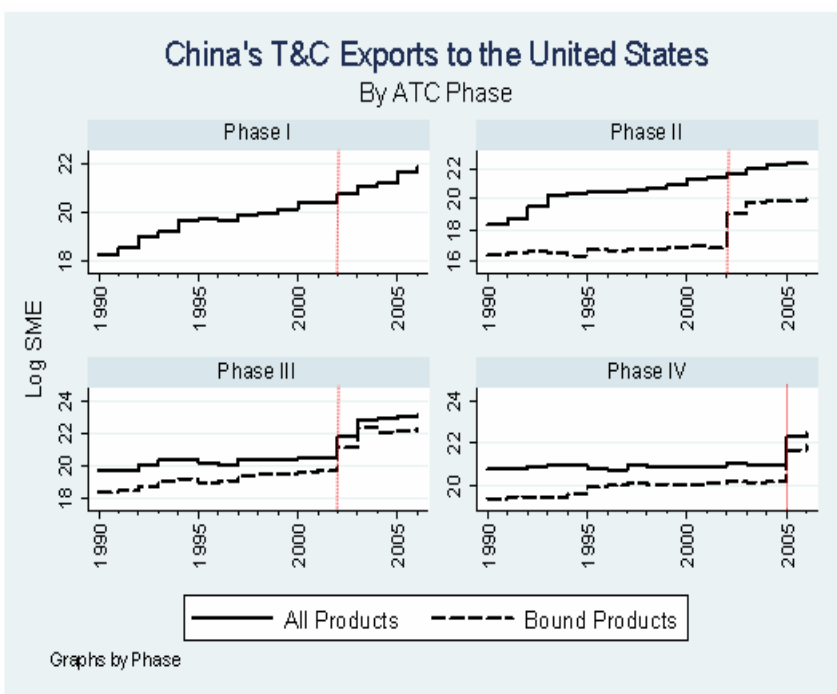

Notes: Bound products are those with $>90 \%$ fill rates one year prior to integration. Log scale approximates actual percentage changes. Red lines display the year in which quotas on the noted goods are phased out.

Figure 1: China's T\&C Exports, by Phase

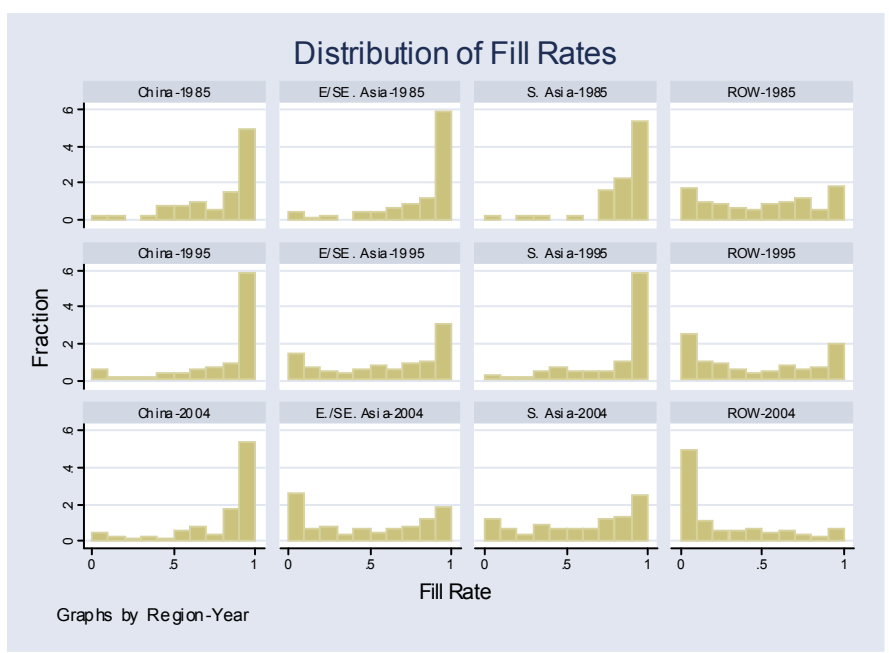

Figure 2: Fill Rates by Region, 1984-2004 


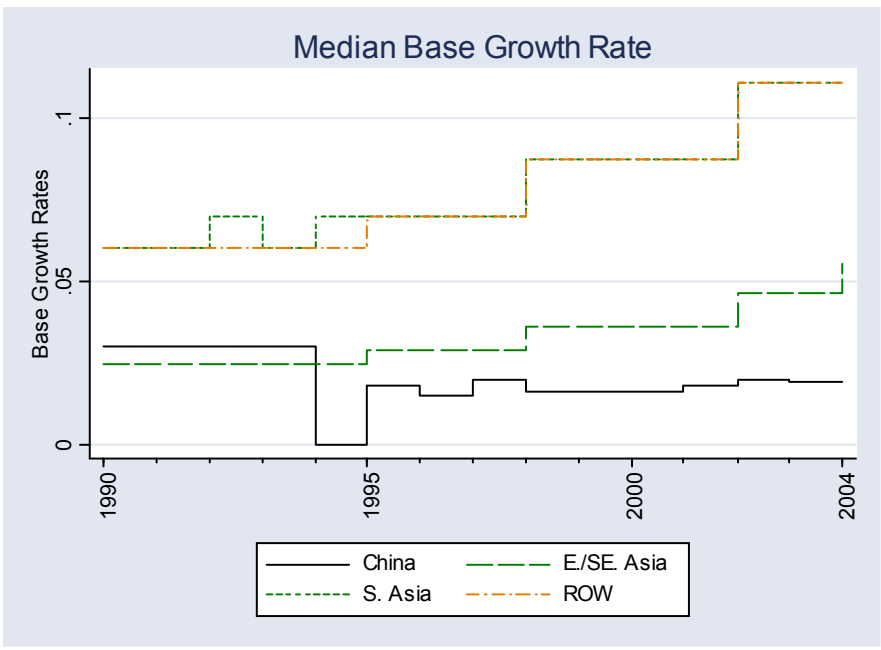

Figure 3: Median Base Growth Rate by Region, 1990-2004

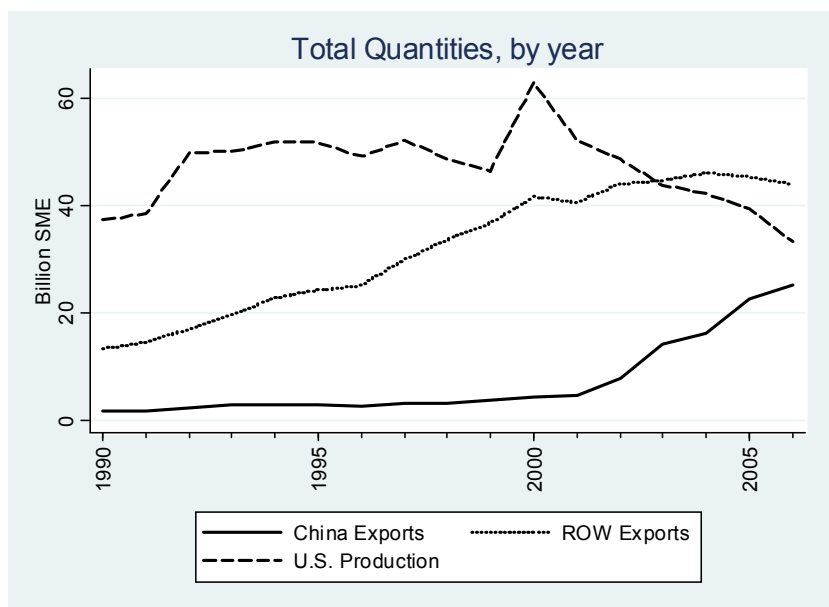

Figure 4: T\&C Quantities, by Region 


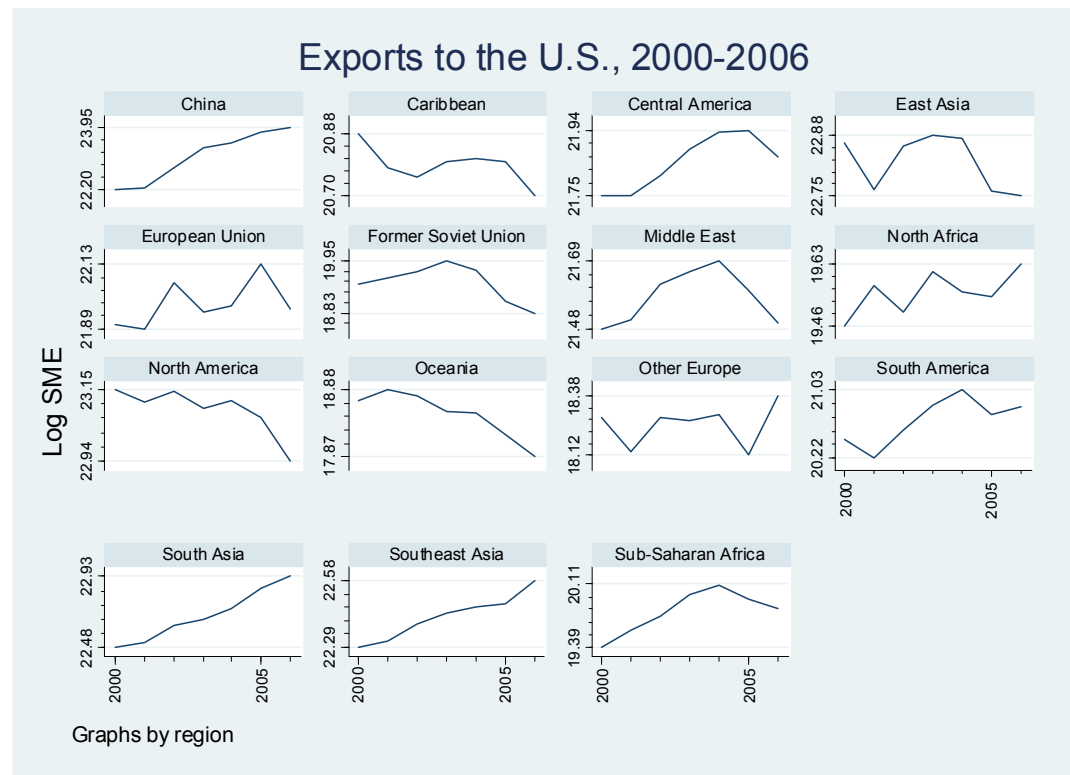

Figure 5: Exports to the U.S., 2000-2006, by Region 